\title{
notas sobre a construção de uma "identidade açoriana" na colonização do sul do Brasil ao século $\mathrm{XVIII}{ }^{1}$
}

Martha Daisson Hameister*

\begin{abstract}
Resumo. Este texto destina-se a contribuir para a discussão da formação de uma "identidade açoriana” durante o processo de conquista e colonização do território meridional do Brasil. Tido como grupo coeso e homogêneo, os “açorianos", assim denominados na historiografia sulina, também teriam, segundo essa mesma historiografia, comportamento homogêneo, fruto de sua origem comum nas Ilhas. Pretende-se demonstrar, no entanto, que a identificação e a identidade desse grupo decorreram, sobretudo, de características especificamente sulinas, de opções e de estratégias empregadas por esses migrantes no extremo Sul do Brasil, não encontrando correlato nos estados do Grão-Pará e Maranhão, para onde, no mesmo período, foram transmigrados ilhéus em número semelhante. Indica-se, portanto, que tal identidade foi historicamente construída na conquista e povoamento sulinos. Palavras-chave: Migração açoriana. Estratégias sociais. Estratégias familiares. Rio Grande do Sul colonial.
\end{abstract}

* Licenciada em História pelo IFCH/UFRGS, mestre em História Social pelo PPGHIS/IFCS/UFRJ e doutoranda pelo mesmo programa. Bolsista FAPERJ.

Anos 90, Porto Alegre, v. 12, n. 21/22, p.53-101, jan./dez. 2005 
Notas sobre a construção de uma "identidade açoriana"...

O intuito deste escrito é discutir a formação de uma "identidade açoriana" durante o processo de ocupação e colonização do então Continente do Rio Grande de São Pedro. Não sendo o objeto central da pesquisa que ora se desenvolve, esse tema tem-se imposto ao longo da investigação, demandando sua problematização e estudo. Assim, o tema é colocado aqui muito mais como uma tentativa de se chamar a atenção para essa questão e propor o seu debate, do que como apresentação de conclusões finais acerca do assunto. Por ser a discussão parte de uma pesquisa maior, ainda em andamento, o que aqui se diz deve ser encarado como resultado parcial, podendo vir a sofrer modificações ao longo do desenvolvimento do estudo. ${ }^{2}$

O estudo focaliza o Rio Grande de São Pedro a partir da atuação de um pároco no ano de 1738, ou seja, antes da elevação do primeiro povoado do Continente - São Pedro do Rio Grande ao estatuto de vila. A pesquisa avança até o período posterior à devolução da Vila de Rio Grande aos portugueses (1776), após sua tomada pelas tropas espanholas em 1763. Para destacar o processo de formação de identidade, foi necessário acompanharemse certas trajetórias familiares. Isso fez com que os recortes, tanto o geográfico quanto o cronológico, fossem constantemente extrapolados, para que não se perdesse a riqueza de detalhes dessas trajetórias que dão sustento às hipóteses que aqui serão levantadas.

Cabe aqui afirmar, antes de tudo, que essa "identidade" nada ou muito pouco tem a ver com a "identidade açoriana" que atualmente e, cada vez mais, se afirma nos estados sulinos entre os descendentes de ilhéus, moradores de localidades por eles fundadas ou povoadas durante o período colonial. Pela exigüidade do espaço, fica esta discussão - a "identidade açoriana" contemporânea - para uma próxima ocasião.

$\mathrm{Na}$ visão corrente, essa "identidade açoriana" é, em muito, associada ao local de origem dos migrantes. Todavia, no desenvol-

Anos 90, Porto Alegre, v. 12, n. 21/22, p.53-101, jan./dez. 2005 
vimento da pesquisa percebeu-se que, no século XVIII, nem todo nativo das Ilhas que habitou o Rio Grande compartilhava do pertencimento ao grupo. Alguns não eram vistos nem se viam como "gentes das Ilhas" ou "Casais de Sua Majestade". Pretende-se, assim, demonstrar que a "identidade açoriana" no século XVIII foi historicamente construída no Continente do Rio Grande de São Pedro. Valem algumas premissas dessa análise também para o caso de Santa Catarina, já que ambos faziam parte de um mesmo processo migratório, regido pelas diretrizes da Coroa lusa, intensificado no Período Pombalino.

Não se fará aqui uma vasta discussão acerca do tema "açorianos" na historiografia. Somente isso já ocuparia um sem-fim de páginas. O que pretende-se destacar aqui é um aspecto comum que perpassa todas as obras das quais se procedeu à leitura, das mais antigas às mais recentes: o fato de "ser açoriano", nos escritos aos quais se teve acesso aparece como coisa dada e não como uma construção que ocorreu ao longo do processo de conquista e povoamento dos territórios meridionais.

Podem ser citadas aqui, a título de exemplo, algumas obras produzidas na historiografia tanto tradicional quanto acadêmica. Os Casais Açorianos, de João Borges Fortes (1999) e A Colonização Açoriana no Rio Grande do Sul, de Henrique Oscar Wiedersphan (1979), são obras da historiografia tradicional que têm os açorianos como objeto e que são permeadas por esta visão: os açorianos como um grupo coeso e homogêneo, dada a sua origem comum. Publicada mais recentemente, há a coletânea de artigos intitulada Açorianos no Brasil, organizada por Véra Lúcia Maciel Barroso (2002) e que reúne textos de produção acadêmica e não-acadêmica. Mais da metade dos artigos nela contidos versam sobre os açorianos no sul do Brasil e, também, na totalidade destes, os imigrantes são vistos do mesmo modo: um grupo já construído como tal desde antes de sua chegada ao Continente, haja vista todos terem a origem comum insulana.

Anos 90, Porto Alegre, v. 12, n. 21/22, p.53-101, jan./dez. 2005 
Notas sobre a construção de uma "identidade açoriana"...

$\mathrm{Na}$ historiografia acadêmica, pode ser citada a obra $A$ Vila do Rio Grande de São Pedro, de Maria Luiza Bertuline Queiroz (1987). Ainda que não sejam os açorianos o tema central desse trabalho, o impacto demográfico causado pela chegada do grande contingente de migrantes ilhéus à Vila de Rio Grande se coloca como tema em cinco subcapítulos. Os açorianos, nessa obra, talvez pelo destaque dado aos aspectos demográficos que a permeiam, também são analisados como uma unidade, um grupo coeso, sem grandes distinções internas e com a origem geográfica a conferir-lhe o traço comum e suficiente para a identidade de seus componentes.

Como último exemplo, a tese de doutoramento recentemente defendida intitulada Sonhos, Desilusões e Formas Provisórias de Existência: os açorianos no Rio Grande de São Pedro, de Cleusa Maria Gomes Graebin (2004). A autora, neste trabalho, se propõe à análise das estratégias de sobrevivência dos açorianos no Rio Grande do Sul durante o século XVIII. Propõe também o estudo da vida cotidiana desse grupo. Preocupada com a construção da imagem e das representações do açoriano na historiografia regional, entretanto, a autora não concebe o fato da construção e consolidação de um grupo identitário com origem e interesses comuns como sendo, também, uma estratégia, e portanto, fruto de escolhas e de opções que se ofereciam ou que eram possíveis nessa sociedade. Tampouco analisa a possibilidade de algumas famílias de origem insulana não compartilharem do pertencimento ao grupo. $\mathrm{O}$ trabalho de Graebin, que também se utiliza das fontes paroquiais do Arquivo Histórico da Cúria Metropolitana de Porto Alegre cedidas por Vanessa Gomes de Campos, colocadas em seus anexos, não detecta, a partir dessas e outras fontes, as grandes diferenças sociais existentes entre os migrantes insulanos. Essas diferença já foram apontadas na monografia de Adriano Comissoli (2002) sobre os Casais de Sua Majestade em Viamão. Boa parte dessas diferenças, pensa-se aqui, preexistiam nas localidades de origem.

Anos 90, Porto Alegre, v. 12, n. 21/22, p.53-101, jan./dez. 2005 
Assim, mesmo nos trabalhos mais recentes sobre "os açorianos", encontra-se presente o tal traço comum: "ser açoriano" antecede a chegada ao Continente do Rio Grande de São Pedro. É a origem no arquipélago que determina o pertencimento ao grupo, que possui características homogêneas. "Ser açoriano" também é, nessas obras, uma situação predeterminada pelo local de nascimento e não uma relação entre um certo grupo de pessoas e aquilo que encontraram na nova localidade para aonde se dirigiram. "Ser açoriano" é, para todas as obras lidas, uma situação atemporal e

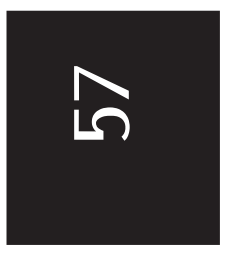
imutável, não aparecendo como processo dinâmico ocorrido em tempo e local específicos, ou seja, não é considerado um processo histórico.

Pretende-se indicar, ao longo deste escrito, que não basta uma origem geográfica comum para dar as características necessárias para a inclusão nesse grupo. Assim como muitos dos migrantes dos Açores eram parte dos casais ou eram ditos das ilhas, alguns não eram vistos assim e nem assim se percebiam. Ao contrário, pretende-se mostrar que uma identidade como essa somente é construída em algumas ocasiões, fruto das condicionantes e das escolhas possíveis em um determinado local e um determinado momento histórico. A construção dessa identidade foi, afirma-se aqui, antes de mais nada uma opção dos nativos das Ilhas. Não era compartilhada de maneira homogênea com todos que de lá vieram. Tampouco foi opção adotada pelos ilhéus em todas as localidades para as quais migraram. Mais do que isso, era um grupo, de alguma forma, "permeável", que permitia, por meio do casamento ou de outras formas de aproximação, que outros elementos ingressassem em suas fileiras, passando a gozar de prerrogativas pertinentes ao conjunto. Ou ao contrário, que determinadas pessoas ou famílias se distanciassem do grupo ao qual originalmente eram ligadas.

Em nenhum dos documentos utilizados nessa pesquisa, tais migrantes eram ditos ou se diziam "açorianos". Antes, as desinências mais comuns para tais homens e suas famílias eram as de gente das 
Notas sobre a construção de uma "identidade açoriana"...

Ilhas, dos Casais de Sua Majestade, dos Casais de Número ou simplesmente dos Casais. Isso leva a crer que mesmo a idéia de o Arquipélago dos Açores ser uma unidade geográfica suficiente para conferir traço comum aos seus naturais é posterior à chegada e ao estabelecimento dos "açorianos" no Continente do Rio Grande de São Pedro. Muitas vezes, a ilha de origem se sobrepõe, em importância, ao próprio arquipélago. O termo "açoriano", portanto, soa anacrônico para a realidade estudada. A origem de seu emprego também pode ser investigada por historiadores, que muito provavelmente encontrarão o seu enraizamento na historiografia nacionalista das primeiras décadas do século XX.

O termo "açoriano" será empregado doravante, no máximo, como indicação de origem geográfica e não mais como designação de um grupo. Essa ressalva é significativa, pois a autodenominação e a desinência por outros é de fundamental importância para forjar e manter a identidade de um grupo quando em contato com outros grupos (Barth, 2000, p. 25-67). Nesse pressuposto, baseia-se este texto. Sobre outros aspectos, a discussão assumirá forma pontual ao longo do texto, na medida em que algumas questões colocadas a tornem necessária.

Também é necessário alertar para o fato de que, para um melhor entendimento das questões aqui levantadas, será esboçada uma comparação com o caso dos imigrantes ilhéus trasladados para o Estado do Grão-Pará e Maranhão no mesmo período em que eram enviados açorianos para o Continente do Rio Grande de São Pedro. Tal comparação não será feita a partir de pesquisa em manuscritos, mas com base no trabalho da professora Rosa Elisabeth Acevedo Marin, da Universidade Federal do Pará, complementado com algumas fontes impressas sobre o Período Pombalino no Pará como mediadores (Cortesão, 1951; Mendonça, 1963; Mendonça, 1989; Acevedo Marin, 2002).

Como um dos procedimentos metodológicos, vem sendo empregada, na pesquisa em questão, uma base de dados, denomi-

Anos 90, Porto Alegre, v. 12, n. 21/22, p.53-101, jan./dez. 2005 
nada Gentes, na qual os agentes sociais são fichados por seu nome próprio. Essa é a principal ferramenta de sua identificação e busca, como decorrência do proposto por Carlo Ginzburg (1989, p.169178) em O Nome e o Como. Também como decorrência das propostas de Ginzburg, tem-se que toda a sorte de documentos referentes a esses agentes sociais, que paulatinamente vêm sendo incorporados à base de dados, fornecem dados acerca de suas vidas e, portanto, são considerados. Tais informações são inseridas nessa base de dados, confeccionada no software Microsoft Access, tentando contemplar a mais variada gama possível de facetas das atuações desses agentes na sociedade que se formava no Continente do Rio Grande de São Pedro. Atualmente conta-se com mais de três mil e quinhentas fichas nominais, algumas bastante completas, outras apenas com dados esparsos.

Ainda que se discorde acerca de ser o nome, este identificador, o "caractere único" na sociedade estudada, como quer Ginzburg, dada a recorrência da utilização de homônimos nos domínios lusos, pensa-se ser essa uma boa maneira de dar seqüência ao traba1ho. A pesquisa em andamento contempla essas e outras dificuldades, na tentativa de aprimorar a utilização dos nomes como identificadores, já esboçada em outro trabalho. O texto de trabalho intitulado O Segredo do Pajé: o nome como um bem é uma tentativa de "refinamento" e de adequação desse método onomástico, bem como de problematização da questão dos nomes próprios dos sujeitos históricos e o papel dos homônimos no período colonial (Hameister, 2003b), e será incorporado ao texto final da tese que ora se elabora.

Não se pode desprezar, também, as características dos acervos documentais relativos ao Brasil e em especial ao período colonial, quais sejam, a existência de lacunas nas séries documentais devido a roubos, incêndios, péssimo estado de conservação de muitos códices, além da inacessibilidade a certos arquivos e acervos, principalmente os privados. Essa realidade fez com que 
Notas sobre a construção de uma "identidade açoriana"...

João Fragoso denominasse esta tentativa de análise micro-histórica no Brasil de "micro-história tapuia". "Tapuia" pois é feia, lacunar, carente de grandes séries documentais (Fragoso, 2002, p. 63). Nessa perspectiva - cobrir as lacunas da documentação por meio da utilização intensiva das fontes e cruzamento de seus dados -, é que esta pesquisa se insere. A micro-história italiana e seus métodos são, portanto, base para este estudo. Todavia, dada a precariedade da documentação, o resultado está muito distante daquele "belo e bem acabado" que costumam obter os historiadores europeus que optam por essa abordagem. Tentando suprir tais deficiências, ainda segundo Fragoso (2002 p.63), faz-se necessário buscar regularidades e fenômenos reiterados ao longo do tempo e recorrer à teoria como forma de explicar os fenômenos históricos. "Mesmo a identificação de uma experiência única só é possível através das práticas rotineiras".

A discussão será apresentada, aqui, em cinco partes. Na primeira será feita uma digressão para situar o contexto em que se deu o início do povoamento da Vila do Rio Grande. Após, uma exposição das situações de emigração nas Ilhas, bem como a reiterada vinda de migrantes dos Açores para a América portuguesa. $\mathrm{Na}$ terceira parte, com base no bem documentado exemplo de um fidalgo madeirense que engajou a si e a sua família em uma das levas migratórias saídas do arquipélago dos Açores, discorre-se um pouco sobre situação dos filhos segundos das boas famílias de ilhéus e sobre a diferenciação de estatuto social entre os próprios migrantes. A quarta parte apresenta, por meio da parca documentação encontrada a esse respeito, a percepção dessa diferenciação social nas famílias que saíram dos Açores e chegaram ao Continente do Rio Grande de São Pedro. Na quinta e última parte, a partir de uma breve comparação com o caso dos migrantes dos Açores enviados para o Estado do Pará e Maranhão, estudado por Acevedo Marin, discutem-se os motivos que levaram "os casais de Sua 
Majestade", no sul do Estado do Brasil, a construírem uma identidade de Ilhéus ou a não necessitarem dela para a sua sobrevivência.

\section{O início da povoação da Vila do Rio Grande e a posse dos territórios de Sua Majestade}

"Para dar calor à nova povoação" que se estabelecia à margem da Barra da Lagoa dos Patos, à sombra protetora da fortificação de Jesus-Maria-José, erigida sob o comando de José da Silva Paes, tratou-se de trasladar populações civis - fossem elas lusas, luso-brasileiras ou indígenas. Especial atenção era dada para que fossem remanejadas as mulheres desimpedidas, sozinhas ou acompanhadas de suas famílias. Grande incentivador do crescimento populacional nas regiões meridionais, o Brigadeiro Silva Pais preocupava-se com as deserções dos soldados. Boa parte deles já havia participado das batalhas em defesa da Colônia do Sacramento. Preocupava-se com a fuga dos mais jovens. Ansiava que, com a presença de mulheres, os casamentos passassem a ocorrer amiúde, gerando laços familiais que, em sua concepção, dariam menos azo às fugas (Fortes, 1980, p. 113).

Primeiramente, Silva Pais, governador do Rio de Janeiro e comandante militar do Rio Grande, tratou de remanejar aquelas que ficaram conhecidas na historiografia como as mozuelas. Eram mulheres da "difícil vida fácil" que foram conduzidas desde o Rio de Janeiro para o Continente do Rio Grande de São Pedro. Solicitou-as também à Bahia, conforme carta de Silva Pais ao Vice-Rei:

Mulheres desimpedidas que lá [Rio Grande] podem casar e que aqui [Rio de Janeiro] eram nocivas, e se Vossa. Excelência dessa cidade [Salvador] manda também algumas (suponho não faltarão) serão úteis, pois servem de raízes que prendem a gente moça que ali existe [...]. (apud Fortes, 1980, p. 113). 
Notas sobre a construção de uma "identidade açoriana"...

Não se sabe se da Bahia também vieram as "recrutas", mas existem registros de batismos nessas primeiras décadas da localidade de Rio Grande de São Pedro de mulheres da Bahia sendo madrinhas de algumas crianças ou tendo filhos naturais ou legítimos com homens de procedências diversas - e.g. batismo de João, 03/06/1747, e batismo de Mariana, 19/07/1750 (Arquivo da Diocese..., 1LBatRG). Esses dão margem para que se pense que o Vice-Rei também tenha enviado as tais "mulheres nocivas".

Num tom panegírico à terra, Silva Paes, em outra missiva, falava do êxito de seu "exército feminino" ao Prior de Chaves:

[...] podendo segurar que é o melhor clima que tem na América, pois ainda ali se não experimentou, nem houve sezões, nem febres malignas, e Mulheres que eu tinha mandado do Rio, as mais corridas, e Galicadas sem cura melhoraram, e pariram quase todas. ${ }^{3}$

Após sua saída do comando da fortificação e da governança militar do presídio e do Continente, foi nomeado seu sucessor. Um guerreiro experimentado em três continentes passou a responder pela Comandância Militar do Rio Grande de São Pedro. ${ }^{4} \mathrm{O}$ Mestre-de-Campo André Ribeiro Coutinho também preocupou-se em acolher gente disposta a "dar calor à povoação". Durante seu serviço na Comandância, foram chegando povoadores, além dos soldados, dos peões, dos condutores de tropas e das mozuelas. Foram remanejados outros contingentes populacionais, desde casais de outras áreas da Colônia até os ditos "índios de Sua Majestade", muitos dos quais vindos de São Paulo, para o bom serviço de ElRei (Coutinho, 2002).

Entre outros motivos para promover o povoamento, há o de que, já em meados da década de 1730, os tratados de fronteira com Espanha, baseados no Tratado de Tordesilhas e na tese dos limites naturais, estavam com seus dias contados. As terras do Continente do Rio Grande de São Pedro ficavam todas para além dos

Anos 90, Porto Alegre, v. 12, n. 21/22, p.53-101, jan./dez. 2005 
territórios portugueses assinalados pelo Tratado de Tordesilhas. Foram, durante todo o século XVIII, motivo de disputa entre as duas Coroas ibéricas. Se por um lado os avanços em direção ao Sul e ao Oeste, buscando os tais limites naturais, davam sinais de falência nas tratativas diplomáticas, por outro os tais avanços, na prática, prosseguiam com muita força. Já se esboçava, desde a década de 1730, elementos para fazer valer a tese do utis possidetis. Ou seja, em algum momento futuro das negociações, cada uma das duas nações européias ficaria com o exato território que estivesse sob seus pés (Prado, 2002, p. 57-58).

Até a década de 1740, a "caça aos gados", com finalidade de extração de couros era responsável pela maior parte da produção comercializável e das receitas que ingressavam no extremo-sul do Estado do Brasil (Porto, 1943 p. 354-355). Mas ao que tudo indica, essa atividade dava mostras de declínio, devido à extinção dos animais (Coutinho, 2002; Hameister, 2002 p. 186-198). A conduta de tropas de eqüinos, bovinos e muares, enviadas para São Paulo e Minas Gerais, era a nova possibilidade de obter dinheiro e mercadorias para comércio ao retornar da viagem (Hameister, 2002, p. 186-193). Todavia, os habitantes da localidade sulina deveriam dedicar-se também à agricultura. Deveriam prover seus próprios alimentos.

A missão de tomar conhecimento dos territórios interioranos e desenhar seus mapas, delegada aos padres geógrafos Domingos Capaci e Diogo Soares, tentava, para a Coroa de Portugal, dar conta dos mais longínquos rincões por onde andavam seus súditos. Sem nenhum exagero, os padres tomaram ciência, um tanto por suas viagens, outro tanto por informações tomadas de homens experimentados nos inóspitos caminhos, desde o Rio da Prata até Belém do Pará, dos caminhos litorâneos àquilo que ainda viria a ser chamado de Região do Pantanal (Notícias Práticas, 2002). Antevendo uma guinada na diplomacia das fronteiras, assinalavam qualquer agrupamento de choças onde habitassem os lusos ou gente leal à

Anos 90, Porto Alegre, v. 12, n. 21/22, p.53-101, jan./dez. 2005 
Notas sobre a construção de uma "identidade açoriana"...

Coroa Portuguesa. Portugal precisava ocupar efetivamente todo o território que conseguisse, para argumentar posteriormente que a terra era sua, por direito de posse.

Distante dos outros povoados de posse lusa inconteste, a Colônia do Sacramento era uma estrela sem constelação. Sua fragilidade aos ataques espanhóis, dado seu isolamento, ficara evidente durante o cerco que estes promoveram e que durou de 1735 a 1737, quando foi quase perdida para os inimigos da outra margem do Rio da Prata (Monteiro, 1937; Prado, 2002). Em 1737, portanto, ficou patente a necessidade de outros povoados que servissem simultaneamente de apoio a Sacramento e de porta de entrada às miríades de gados. Os gados estavam inacessíveis pelo norte de Sacramento desde que os espanhóis ergueram o Campo de Bloqueio àquela praça. Também era desejável que o novo povoado que margeava a Barra da Lagoa dos Patos servisse de pólo irradiador de povoadores, que adentrassem mais e mais as terras do interior, com suas casas, lavouras e benfeitorias, para quando as novas tratativas de limites chegassem a gerar um acordo. Isso só ocorreria em 1750, quando foi assinado o Tratado de Madri. Urgia, portanto, por esses diversos motivos, a povoação do extremo-sul. Era de suma importância reverter a situação de seu litoral ermo e o interior, a esse tempo, pontilhado pelas Missões dos Jesuítas espanhóis e suas estâncias e reduções repletas de indígenas.

\section{Os povoadores vindos das Ilhas para a América}

O início da chegada dos açorianos à Vila do Rio Grande, desde a década de 1750, trouxe a esse povoado de fundação recente - menos de quinze anos se passaram desde que o Forte fora erigido - um grande contingente de famílias migradas em conjunto. Não mais as mozuelas de vida desregrada, "regeneráveis" na nova vida na nova localidade. Vieram famílias inteiras, migradas

Anos 90, Porto Alegre, v. 12, n. 21/22, p.53-101, jan./dez. 2005 
do Arquipélago dos Açores em atenção às solicitações de Gomes Freire de Andrade e de seu colaborador José da Silva Pais. ${ }^{5}$

Ainda que trasladar casais das Ilhas para a porção sul dos territórios lusos na América fosse uma novidade, não o era no processo de expansão do Império Português em direção ao Novo Mundo. Datam de 1550 as primeiras solicitações de povoadores para a Bahia, ${ }^{6}$ ou seja, apenas cinqüenta anos tinham se passado desde o achado de Cabral. Por seu lado, as Ilhas mal tinham completado cem anos desde que foram ocupadas por migrantes vindos do norte de Portugal e da Madeira, além de um significativo grupo de estrangeiros: flamengos em sua maioria e, em menor número, genoveses, ingleses e outros mais (Vieira, 1992, p. 53-103).

$\mathrm{O}$ argumento da Coroa, usado para proceder tal transporte, passava primeiramente pelos desastres naturais. Estes faziam das Ilhas dos Açores um local muito arriscado: os vulcões do arquipélago lançavam constantemente pedras, fumaça, cinzas e lava de suas entranhas. Deitavam fogo sobre a lavoura e a criação, expulsando as famílias de suas casas, deixando como terra arrasada algumas vilas e povoados. Por outro lado, ao final da travessia do Atlântico havia terras de dimensões quase infinitas, o solo era bom. Assim diziam as notícias: uma terra imensa em que "se plantando tudo dá". Entretanto, terra esta carente de povoadores, tanto agricultores como gente de ofício: carpinteiros, ferreiros, pedreiros e outros mais, necessários para "construir" a sociedade e seus bens materiais (Cortesão, 1951, p. 411). Afinal, na terra do pau-brasil tudo ainda estava por fazer. Assim, a Coroa propunha o que aqui será chamado de duplo remédio: para as populações de insulanos, a possibilidade de viverem de modo mais próspero, sem as catástrofes que lhes destruíam casas e plantações; para as novas terras, gente que as povoasse, que estendesse, que ampliasse, no alémmar, os domínios povoados de Sua Majestade. Assim foi feito nesses primeiros momentos.

Já no século XVII, além da Bahia, tiveram vez Pernambuco, Grão-Pará e Maranhão, Rio de Janeiro, sempre avançando, atingindo

Anos 90, Porto Alegre, v. 12, n. 21/22, p.53-101, jan./dez. 2005 
Notas sobre a construção de uma "identidade açoriana"...

São Paulo e o interior da Amazônia. Tem-se a impressão de que, sempre que as expedições militares ou chefiadas por particulares adentravam um novo território, solicitavam, imediatamente após, povoadores. As expedições entravam em contato com indígenas, promovendo seu apresamento para servirem de mão-de-obra nas lavouras, colocavam-nas a "correr para os matos", contagiavamnas com doenças ou, por vezes, dizimavam as aldeias daqueles a quem não podiam submeter. Via de regra, os novos povoadores eram requeridos aos Açores (Cortesão, 1951, p. 395-493). Porém, no século XVII, não apenas as catástrofes naturais impunham fome e necessidade nas Ilhas. Outros problemas surgiam no Arquipélago, causados pela presença humana de um modo geral e pelo sistema agrário português de um modo mais específico.

Nos Açores, assim como em outras partes de Portugal, as grandes porções de terras eram propriedades indivisíveis das famílias nobres. As formas de sucessão e a indivisibilidade das terras existentes no direito consuetudinário, mais precisamente na Lei Mental, foram especificadas nas Ordenações Filipinas, regulamentando e esclarecendo dúvidas relativas às interpretações da lei não escrita (Almeida, 1870, Livro 2, Tit. 35-37, p. 454-463).

As terras das famílias nobres deveriam ser, segundo o sistema de herança que regia a transmissão de propriedades de raiz da nobreza, repassadas apenas ao primogênito, o único herdeiro delas, deixando para os demais filhos apenas a possibilidade de receber bens móveis, se colocados em testamento. Por serem as terras doadas pelo Rei a alguns de seus súditos, em reconhecimento aos bons serviços prestados por famílias em campanhas militares, deveriam seguir na família, não podendo ser alienadas. Os filhos seguintes podiam receber de herança algumas jóias, roupas e tecidos, algum dinheiro, caso a família os tivesse. Mas, a menos que o primogênito viesse a falecer, o filho seguinte na linha sucessória não receberia um grão de terra sequer (Almeida, 1870, Livro 2, Tit. 35, p. 454-462).

Anos 90, Porto Alegre, v. 12, n. 21/22, p.53-101, jan./dez. 2005 
Além das grandes propriedades e morgados das boas famílias, havia no Arquipélago muitas propriedades religiosas, também indivisíveis e inalienáveis. A maior parte dos agricultores que não procediam dessas ricas famílias não possuíam terras. Eram, em sua maioria, camponeses livres que lavravam as terras dos grandes senhores e das ordens religiosas (Vieira, 1992, p. 71). A propriedade fundiária nos Açores, portanto, era em sua maioria concentrada em poucas mãos, não podia ser dividia, tampouco vendida.

Em conjunção com os desastres naturais e com essa concen-

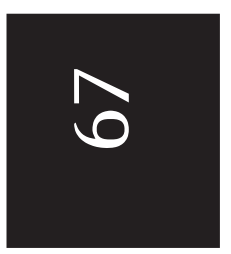
tração das terras nas mãos de poucos senhores e dos conventos e ordens religiosas, as terras dos Açores, ao que tudo indica, não eram muito férteis. Foram exaustivamente exploradas nas lavouras de cana-de-açúcar e pastel - uma erva tintória produzida nessas ilhas -, assim como o trigo para a exportação (Vieira, 1992, p. 136-173). As lavouras com fins de comercialização exigiam muito das qualidades nutritivas do solo que, sem nenhum manejo - adubação, reflorestamento ou outra prática que lhes repusessem os nutrientes - viu-se esgotado e incapaz de prover o sustento daqueles que o lavravam (Vieira, 1992, p. 143 e ss.). Além disso, em intervalos impossíveis de serem previstos, continuavam a acontecer as tais erupções, terremotos e maremotos de vagas imensas, inviabilizando, vez por outra, as safras.

Se, no primeiro momento da migração para a Bahia, eram as erupções vulcânicas e os terremotos os motores da migração, ao século XVIII, houve a explícita insuficiência na produção de alimentos como motivo da emigração. Num dos documentos que tratam do traslado de açorianos para a Colônia do Sacramento, o Parecer do Conselheiro Antônio Rodrigues da Costa, encontra-se o seguinte trecho:

Nos anos seguintes se poderão mandar mais casais, que se poderão tirar das Ilhas, onde são tantos que os não pode sustentar o pequeno terreno que habitam, e a conveniência que se pode tirar daquelas terras fertilíssimas

Anos 90, Porto Alegre, v. 12, n. 21/22, p.53-101, jan./dez. 2005 
Notas sobre a construção de uma "identidade açoriana"...

do Rio da Prata só há de ser pelo meio dos moradores que fazendo assento nela hão de procurar utilidades que pode dar. (Cortesão, 1951, p. 411, grifo meu).

As Ilhas, portanto, sofriam o problema da superpopulação. Não quer dizer, necessariamente, que possuíssem uma população numericamente exagerada em termos absolutos. Mas o exagero existia na relação desse número de habitantes com os recursos e a capacidade ou a disponibilidade das terras em produzir alimentos. O terreno das Ilhas dedicado à produção de grãos e outros gêneros para o consumo local era insuficiente para prover seus habitantes. Para a obtenção do alimento necessário, os proprietários das grandes glebas que também detinham as porções de terras mais férteis teriam que cessar a produção voltada para a comercialização fora das Ilhas. Isso encontrava boa oposição dos grandes senhores que dessas lavouras obtinham sua riqueza. Os Açores eram, com bastante freqüência, a esse tempo, importadores de alimentos. Não foram poucos os conflitos e revoltas causados pela falta de abastecimento (Vieira, 1992, p. 136-203). Eis, então, que fazer migrar os camponeses e os artesãos aliviava essa situação de carência de mantimentos oriundo da pressão demográfica existente no arquipélago.

Aqui faz-se necessário registrar a discordância com Graebin, que afirma em sua tese de doutoramento serem os desastres naturais o motivo maior da retirada de contingentes populacionais de ilhéus em direção à América (Graebin, 2004, p. 80-89). A longeva e reiterada migração de insulanos - a bem da verdade, ela estendeu-se até o século XIX - pensa-se aqui, tinha como impulsionador o mesmo motivo que levava as gentes do norte de Portugal, lugares não afeitos a tantos cataclismos, a deixarem para trás sua terra natal de forma constante e sistemática: o sistema de heranças e propriedade de terras vigente em Portugal. Nas palavras de Jorge Miguel Pedreira (1995, p.207): "regimes sucessórios não igualitá-

Anos 90, Porto Alegre, v. 12, n. 21/22, p.53-101, jan./dez. 2005 
Martha Daisson Hameister

rios que privavam da posse de terra uma grande parte dos descendentes, obrigando-os a abandonar a exploração agrícola".

Entretanto, a migração periódica dessa população necessitada resolvia apenas parte da equação que tem o Atlântico como separador de seus dois membros. As famílias eram conduzidas para a América, podiam viver com maior prosperidade, procriar e povoar os territórios, aliviando a pressão demográfica nos Açores. Todavia, faltava também gente experimentada em mando e administração nas novas colônias que se fundavam no além-mar. Em

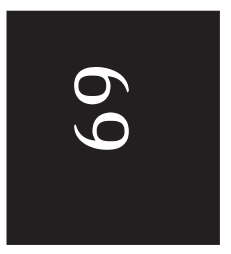
contrapartida, as boas famílias das Ilhas tinham seus filhos segundos distanciados da herança das terras. Também havia de ter solução esse problema.

\section{Os filhos segundos e os novos povoados, por meio do exemplo de uma família madeirense}

A migração dos setores menos aquinhoados resolvia a questão de reduzir a população nas Ilhas e aumentar o número de povoadores nos novos territórios americanos. Mas isso não dava solução ao problema das melhores famílias do Arquipélago, qual seja: o que fazer com os outros filhos das boas famílias que tinham nome, nobreza, prestígio e distinção e o cofre vazio? Ao que tudo indica, facilitar a migração desses outros filhos que não os primogênitos também foi prática corrente nesse século XVIII. Foi, inclusive, subsidiada pela Coroa lusa. Muito provavelmente os chamados segundões não viessem a obter títulos de nobreza nos novos territórios americanos. Poderiam, entretanto, angariar terras e prestígio, aumentando as folhas de serviços próprias e de suas famílias, agindo no interesse de Sua Majestade.

Tem-se o exemplo de Henrique Cesar de Berenger e Bitencourt, migrado para a Ilha de Santa Catarina nos anos que cercam $1750 .^{7}$ Esse homem não era um açoriano, mas um

Anos 90, Porto Alegre, v. 12, n. 21/22, p.53-101, jan./dez. 2005 
Notas sobre a construção de uma "identidade açoriana"...

madeirense, ou seja, não pertencia às Ilhas contempladas com a ênfase migratória para o extremo sul da Colônia dada no Edital de 1747 (Fortes, 1999, p. 26-27).

Segundo Walter Piazza, o engajamento de 59 migrantes da Madeira nos intentos de povoamento do extremo-sul do Estado do Brasil ocorreu por insistentes solicitações de Berenger e Bitencourt, iniciadas em 1746, a despeito de mais de dois mil alistados nos Açores (Piazza, 1997, p. 125). Somente de sua família vieram quinze pessoas. Isso acabou contribuindo para que o arquipélago da Madeira fosse incluído na área de emigração nessa metade do século XVIII (Santos, 1999, p. 110-113).

Berenger e Bitencourt pediu ao Conselho Ultramarino especial atenção ao caso seu e de seus familiares. Solicitou que fossem trasladados para a Ilha de Santa Catarina às custas da Real Fazenda, como os demais migrantes, para dar contribuição para o povoamento, com sua qualidade e com sua experiência em uma situação de mando: fora Capitão da Sala do General, na sua cidade natal, Funchal, capital do Arquipélago da Madeira. ${ }^{8}$ Sua trajetória, das Ilhas Atlânticas ao sul do Estado do Brasil, dá as pistas para entender o drama que se passava com as melhores famílias das Ilhas e como ele era resolvido. Tentava-se solução e, ao mesmo tempo, alívio à pressão demográfica "específica", que pesava sobre os membros dessas famílias nobres, e ao problema da falta de gente de mando nas terras por povoar. Seria esse, também, uma espécie de duplo remédio à situação de "excedente populacional" específica entre os fidalgos.

Berenger e Bitencourt solicitou ao Conselho Ultramarino que lhe fosse permitido embarcar junto com os nativos dos Açores que partiam para a Ilha de Santa Catarina. Argumentava que Sua Majestade teria nele um bom e laborioso súdito. Contando a seu favor, tinha a trajetória de seus ancestrais. Pedia, então, 
[...] atenção ao serviço que tem feito, e seus antepassados e qualidades de sua pessoa, na certeza de que não passará àquelas partes outro de qualquer das Ilhas que o exceda em nobreza [...] para passar à América a povoar aquelas terras incultas com a diferença na ajuda de custo segundo o número de sua família e distinção de sua pessoa. ${ }^{9}$

O Executor do Conselho Ultramarino contribuiu com informações a respeito de Berenger e Bitencourt:

Sem embargo de não ter do suplicante conhecimento, o tive bastante de seu pai, que foi meu condiscípulo nos estudos, é com efeito de famílias ilustres e das primeiras daquela Ilha, que suposto haja na sua casa um morgado ou dois, o suplicante procede de um filho segundo dela e não tem cabedais para conservar-se, com tratamento igual à sua pessoa; e a razão de ficarem pobres os filhos segundos daquela casa foi por seus avós despenderem todo o valor dos bens livres que possuíam, na fundação de um Mosteiro de Religiosas Capuchas de que são os Padroeiros e haverem-no reedificado por duas vezes. (grifos meus). ${ }^{10}$

Houve o reconhecimento das qualidades, suas e de sua família, já que sua solicitação acabou sendo atendida em todos os seus pormenores. Isso o diferenciava, em muito, das demais famílias migrantes.

Pouco tempo após a chegada de Berenger e Bitencourt às terras americanas, encaminhou nova solicitação. Desta vez, além do pedido de ajuda de custo diferenciada, pedia que lhes fossem dadas quatro porções de terra medindo meia légua quadrada. Meia légua para si e meia légua para cada uma de suas três filhas, como dote para o casamento das moças. Talvez por não ter idéia das reais dimensões do território para aonde havia sido enviado, talvez por não saber que os homens que acumulavam serviços à Coroa estavam solicitando e recebendo sesmarias de até "três léguas de

Anos 90, Porto Alegre, v. 12, n. 21/22, p.53-101, jan./dez. 2005 
Notas sobre a construção de uma "identidade açoriana"...

comprido por uma de largo" na década de 1750 (Arquivo..., 1933), solicitara uma parcela de terras muito inferior aos dos "melhores" que se envolviam na conquista dos territórios do extremo-sul da América. Entretanto, o somatório das terras pedidas por Berenger e Bitencourt era de duas léguas de comprido, por meia légua de largura. Isso era uma grande quantidade de terras em comparação ao que se podia obter nas superpovoadas Ilhas portuguesas. Isso também era muito mais do que o quarto de légua em quadro que receberiam os demais ilhéus, ressaltado no próprio parecer do Conselho Ultramarino.

Pedia, também, que lhe fosse dada a patente de Capitão das Ordenanças da localidade onde se estabelecera. Este, assim como seus demais pedidos, foi atendido, com a ressalva em destaque na citação que abaixo segue:

[...] e como o suplicante quer levar na sua companhia 3 filhas, se dê para o casamento de cada uma delas meia légua de terras em quadra de sesmaria, e o mais que se manda a dar a cada um dos casais que naquela parte se estabelecerem, dando-se também ao mesmo suplicante meia légua de terra em quadra, sem embargo de se dar a cada um dos casais um quarto de légua, e vistas as razões que o suplicante refere e informação que dele há, se lhe dêem $150 \$ 000$ rs de ajuda de custo para o seu transporte, com as seguranças necessárias e uma patente de Capitão da Ordenança do distrito aonde se the determinar o seu estabelecimento, com declaração que não terá menos de $\mathbf{5 0}$ casais na sua jurisdição, o que é conveniente acautelar para que se não multipliquem os cargos da ordenança desnecessariamente... (em itálico na publicação, negritos meus). ${ }^{11}$

Supondo-se uma família, constando de pai, mãe e três filhos - ainda que seja um número pequeno de filhos para a época e desconsiderando a existência de outros parentes e agregados Berenger e Bitencourt tinha garantido, sob o seu mando, numa

Anos 90, Porto Alegre, v. 12, n. 21/22, p.53-101, jan./dez. 2005 
estimativa que deve ficar aquém do número real, um mínimo de duzentas e cinqüenta pessoas. Em um território não povoado, isso significa ser o principal poder de uma nova aldeia. Era o líder, nomeado pelo próprio Rei, de praticamente toda a população livre de uma localidade. Na localidade onde Berenger e Bitencourt assentou-se, Desterro, hoje Florianópolis, acumulou os cargos de Capitão de Ordenanças, Juiz de Órfãos, e Juiz Ordinário (Santos, 1999, p. 113).

De forma diferente, aos "casais" recrutados nas Ilhas, o Edital

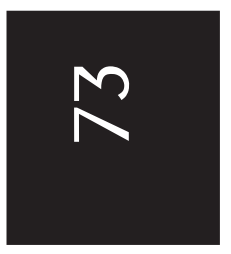
de 1747 colocava apenas uma ajuda de custo de dois mil e quatrocentos réis para cada mulher acima de doze anos que embarcasse, e ajuda "para vestir" de um mil réis para cada filho ou filha, além de insumos e ferramentas (Fortes, 1941, p. 26-27). Ainda que adendos posteriores a esse edital tenham estendido benefícios aos filhos e agregados dos casais, a presteza no atendimento da solicitação desse madeirense não é, nem de longe, comparável aos vinte ou mais anos que levaram os Casais para receber seu quinhão de terras. A Coroa, nas novas terras conquistadas, numa visível redistribuição social das riquezas da conquista, privilegiava alguns em detrimento de outros. Propiciou, na mercê de terras, o dote das filhas do fidalgo segundão da Ilha da Madeira e sua liderança sobre os demais povoadores.

Percebe-se portanto, nos pareceres às solicitações de Henrique Cesar de Berenger e Bitencourt, notada diferença entre o tratamento que ele e sua família receberam e aquele usualmente dispensado aos Casais de Sua Majestade. O filho segundo e demais membros de uma família de nobres vindos das Ilhas, sejam elas do Arquipélago dos Açores ou da Madeira, não eram igualados aos demais habitantes que migraram para a América. As diferenças de estatuto social não se esvaeciam na migração. Isso é plenamente compatível com a idéia de justiça distributiva vigente nas sociedades mediterrâneas de Antigo Regime, as quais possuíam uma forte hierarquização social. Uma desigual distribuição social de recursos,

Anos 90, Porto Alegre, v. 12, n. 21/22, p.53-101, jan./dez. 2005 
Notas sobre a construção de uma "identidade açoriana"...

pois os homens possuem diferentes qualidades, e ainda assim justa, pois a cada um há o quinhão que lhe compete de acordo com uma avaliação de seus pares e coevos sobre sua posição nessa sociedade (Levi, 2002).

Semelhante ao caso de Berenger e Bitencourt, tem-se a família de Antônio Rodrigues Carneiro, trasmontano que conduzira casais de sua região para a Colônia do Sacramento. Rodrigues Carneiro foi agraciado com a patente de Sargento-Mor daquela praça, com soldo equivalente aos sargentos-mores dos Terços do Rio de Janeiro, além da superintendência do linho-cânhamo. Os homens prometidos como noivos às suas quatro filhas receberam patentes de Alferes e Tenentes, também sendo transportados às custas da Coroa, conforme disposto no Parecer do Conselheiro Antônio Rodrigues da Costa (Cortesão, 1951, p. 413).

Ainda de acordo com o Parecer do Conselheiro Antônio Rodrigues da Costa, a cada um dos casais de trasmontanos foi dado, além de ferramentas e sementes, um tostão por cabeça a cada dia de viagem, supondo-se 4 pessoas em cada casal, como ajuda "para se fardar", a quantia de $12 \$ 000$ por casal. Em terras seriam-lhes dadas "10 jeiras de terra em quadra, para nelas poderem fazer roças, currais e o mais que lhe parecer em benefício próprio", equivalendo uma jeira a 400 braças ou 0,2 hectare (Cortesão, 1951, p. 414). Todavia,

Ao Capitão Antônio Rodrigues Carneiro parece se devem dar 20 jeiras de terra na vizinhança da praça e duas léguas em quadra no território e para fazer a jornada para esta Corte e conduzir a sua família $60 \$ 000$ e para se fardar $120 \$ 000$ (Cortesão, 1951, p. 413-415).

O território, portanto, era novo, mas a estrutura social era calcada na velha sociedade portuguesa do Antigo Regime, que muita distinção fazia entre os homens livres. Eram todos povoadores, mas uns já partiam das ilhas ou da península com possibili-

Anos 90, Porto Alegre, v. 12, n. 21/22, p.53-101, jan./dez. 2005 
Martha Daisson Hameister

dades de obtenção de patentes e mercês diferenciadas. A acumulação de bens, poder de mando e prestígio eram possibilitados a algumas famílias, ou seja, a quem já tinha um lastro familiar e aquilo que poderia se chamar de "um bom berço".

A responsabilidade do mando em uma sociedade recente recaía, então, sobre membros de antigas e boas famílias portuguesas, considerando aqui as Ilhas como a última fronteira atlântica do território português em toda a acepção desses termos, não como colônias de Portugal. A estruturação da sociedade nas colônias do

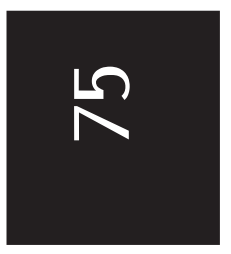
extremo-sul da América, portanto, era moldada na mesma forma da sociedade portuguesa de Antigo Regime, ou seja, calcada nas diferenças de estatuto social entre os homens livres, na hierarquia, na distribuição desigual dos recursos. Um camponês ou um artífice não se igualava a Berenger e Bitencourt em origens e qualidades.

A segunda parte da equação encontrava, assim, uma solução plausível. Os segundões da nobreza das Ilhas partiam para as novas terras recém-conquistadas. Agregavam o atributo oriundo do desbravamento das terras e da formação de novos povoados às folhas de serviço de suas famílias, já aludidas nos registros documentais como sendo dos primeiros povoadores das Ilhas atlânticas, aumentando assim as suas qualidades e os seus préstimos no "Real Serviço de Sua Majestade".

Ao redor desses segundões e suas famílias organizava-se a sociedade. Davam seqüência a trajetórias familiares que reuniam prestígio, terras, riquezas e poder de mando. Sua migração aliviava a "pressão demográfica específica" das famílias nobres, ao mesmo tempo em que contribuía para dar ordem ao caos preexistente, dar ordem a algo que não passaria de um aglomerado de pessoas, caso lhes faltassem os esteios da organização social conhecida. As famílias de baixo estatuto social, sem ter quem os dirigisse e os colocasse no caminho do bem-servir à Coroa, da qual eram súditos, talvez não levassem a bom termo a colonização americana. Os fidalgos "empobrecidos" contribuíam, assim, com sua presença e

Anos 90, Porto Alegre, v. 12, n. 21/22, p.53-101, jan./dez. 2005 
Notas sobre a construção de uma "identidade açoriana"...

com sua posição nos novos povoados para que, em tudo, a ordem sobrepujasse o caos nos novos territórios de Sua Majestade.

Em se tratando de estratégias, a migração para a América demonstrou ser uma possibilidade de sobrevida às famílias fidalgas, por meio de seus filhos segundos. Tanto quanto era uma perspectiva de alívio de uma situação de fome iminente que sempre assombrava os despossuídos agricultores ilhéus. Um mesmo fenômeno histórico - a migração para terras americanas - possuía, então, significados e importâncias diferentes para os agentes sociais, diferenças essas associadas às diferenças sociais preexistentes nas Ilhas.

\section{As boas famílias dos Açores e o povoamento do Rio Grande}

Para o Continente do Rio Grande de São Pedro, encontramse casos semelhantes ao desse "pobre nobre" madeirense e do Capitão trasmontano. Ainda que não se tenham encontrado explicitamente solicitações ou pareceres do Conselho Ultramarino que os diferenciassem, tais como as citadas no tópico anterior, é muito pouco provável que houvesse tanta diferença nas práticas da Coroa e dos ilhéus. Eles eram portugueses e como portugueses se organizavam. Eis aqui o papel das regularidades percebidas ao longo do tempo e em diferentes locais a ajudar a suprir as lacunas da documentação. Encontraram-se, todavia, referências menos substanciosas em seus conteúdos, mas que deixam antever distância entre certas famílias de insulanos e o restante dos migrados.

As filhas de Antônio Furtado de Mendonça e Isabel da Silveira, oriundos da Ilha do Faial, freguesia de São Salvador da Vila da Horta, por exemplo, têm o tratamento de "Dona" desde que chegaram ao Continente (Arquivo da Diocese..., 1738-1763). Também verificou-se que seus maridos não faziam parte do con-

Anos 90, Porto Alegre, v. 12, n. 21/22, p.53-101, jan./dez. 2005 
tingente de camponeses de poucas posses ou de homens de ofício. Essas moças, em sua maioria solteiras quando da chegada, casaram-se dentro do seleto grupo de detentores de sesmarias de grandes proporções, de grandes rebanhos de gado, arrematadores de contratos e oficiais da Câmara, conforme se verá a seguir. As moças de sobrenome Silveira, da família Furtado de Mendonça, destacavam-se do conjunto dos insulanos, mesmo quando casadas com insulanos.

Tanto as filhas de Antônio Furtado de Mendonça quanto os

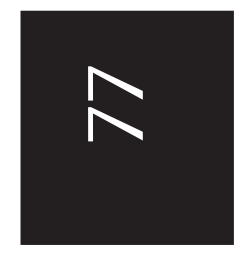
seus genros não compartilharam dos momentos de penúria que atingiram os migrantes dos Açores à sua chegada no Continente. Veja-se, a seguir, a qualidade das relações sociais estabelecidas por esse grupo de migrantes, cujas conexões foram identificadas com base nos registros de batismo dos filhos de um desses casais. Francisco Pires Casado, filho de Francisco Pires Casado e Felipa Antônia da Silveira, natural da Ilha do Pico, freguesia de Santa Luzia, era casado com Dona Mariana Eufrásia da Silveira, filha de Antônio Furtado de Mendonça e Isabel da Silveira. Ela era natural da Ilha do Faial, freguesia de São Salvador da Vila da Horta. Provavelmente as mães de Francisco e de Mariana Eufrásia guardavam parentesco próximo. O pai de Dona Mariana Eufrásia, falecido antes de 1761, era alferes, provavelmente da Companhia da Ordenança (Jaccottet; Minetti, 2001, p. 61).

No ano de 1778, em seu domicílio na freguesia de Viamão estavam arrolados, além de familiares e agregados, 19 escravos. Francisco Pires Casado, em registro documental de 1784, detinha campos em sociedade com Manuel Bento da Rocha, nos quais animais foram contados em quantidade - "8000 animais vacunares, 700 animais cavalares, 90 burros/burras, 30 bois mansos, 100 mulas 60 cavalos mansos e 300 ovelhas". No $1^{\circ}$ Livro de Óbitos da Freguesia de Viamão, é dito Capitão (Arquivo Histórico da Cúria..., 1778; Arquivo Histórico do Estado..., 1778, códs. F1198 A e B1784; Neumann, Kühn, prelo). Francisco Pires Casado e Dona 
Notas sobre a construção de uma "identidade açoriana"...

Mariana Eufrásia tiveram no mínimo quatro filhos batizados na Vila do Rio Grande, os quais também registram os padrinhos, nomeados no Quadro 1.

Quadro 1 - Compadrio de Francisco Pires Casado e Dona Mariana Eufrásia

\begin{tabular}{|l|c|l|l|l|l|}
\hline Criança & Data bat. & \multicolumn{1}{|c|}{ Padrinho } & Nat. padrinho & \multicolumn{1}{|c|}{ Madrinha } & Nat. madrinha \\
\hline Rosália & $12 / 01 / 1755$ & $\begin{array}{l}\text { Francisco Antônio } \\
\text { da Silveira }\end{array}$ & Das Ilhas & $\begin{array}{l}\text { D. Joana } \\
\text { Margarida da } \\
\text { Silveira }\end{array}$ & $\begin{array}{l}\text { Faial, fr. S. } \\
\text { Salvador da Vila } \\
\text { da Horta }\end{array}$ \\
\hline Maurícia & $01 / 10 / 1758$ & $\begin{array}{l}\text { Manuel Fernandes } \\
\text { Vieira }\end{array}$ & $\begin{array}{l}\text { Braga, Póvoa } \\
\text { de Lanhoso }\end{array}$ & $\begin{array}{l}\text { D. Maria Antônia } \\
\text { da Silveira }\end{array}$ & $\begin{array}{l}\text { Faial, fr. S. } \\
\text { Salvador da Vila } \\
\text { da Horta }\end{array}$ \\
\hline Manuel & $17 / 02 / 1760$ & $\begin{array}{l}\text { Manuel Bento da } \\
\text { Rocha }\end{array}$ & $\begin{array}{l}\text { não consta } \\
\text { (península?) }\end{array}$ & $\begin{array}{l}\text { D. Isabel } \\
\text { Francisca da } \\
\text { Silveira }\end{array}$ & $\begin{array}{l}\text { Faial, fr. S. } \\
\text { Salvador da Vila } \\
\text { da Horta }\end{array}$ \\
\hline Francisca & $02 / 08 / 1762$ & $\begin{array}{l}\text { Domingos de } \\
\text { Lima Veiga }\end{array}$ & Portugal & Não consta & Não consta \\
\hline
\end{tabular}

Fonte: Jaccottet \& Minetti (2001).

Vejam-se agora, quem eram os padrinhos dos filhos desse casal e com quem guardavam relações, fossem estas de parentesco sangüíneo, parentesco afim, parentesco fictício ou de negócios.

Francisco Antônio da Silveira. Provavelmente irmão ou primo de Dona Mariana Eufrásia da Silveira, casado com Úrsula Maria da Conceição. Além da menina Rosália, possui apenas um outro afilhado, juntamente com Úrsula. A madrinha não compareceu à cerimônia desse segundo afilhado, dando procuração para que a representassem na cerimônia (Jaccottet; Minetti, 2002, p. 93). Francisco Antônio possuía, em 1767, marca de gado registrada nos livros da Câmara de Viamão (Fortes, 1941, p. 175).

Manuel Fernandes Vieira. Natural de Povoa de Lanhoso, arcebispado de Braga, freguesia de Fonte da Arcada. Casado com Dona Ana Inácia da Silveira, natural da Ilha do Faial, fr. São Salvador da Vila da Horta, irmã de Dona Maria Eufrásia. Dos batismos levantados até o momento, Manuel Fernandes Vieira foi pa- 
drinho de quatro crianças, incluindo a filha de Pires Casado. Fernandes Vieira deve ter chegado ao Continente por volta de 1751, com os contingentes convocados por Gomes Freire de Andrade para a expedição de demarcação de limites do Tratado de Madri. Em 1752 foi nomeado Tabelião da Vila do Rio Grande, podendo ter renovação do cargo em seis meses. Essa renovação deu-se várias vezes, sendo-lhe acrescentado ainda ofício de Escrivão de Órfãos da Vila do Rio Grande. Teve sucessivamente as patentes de Sargento-supra da Ordenança e de Capitão da mesma compa-

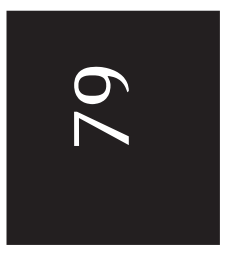
nhia, todas essas mercês dadas ou ratificadas por Gomes Freire de Andrade (Arquivo Público..., 1929, p. 452, 488, 574). Ainda na Vila do Rio Grande, foi Contratador dos Açougues, em sociedade com Manuel Bento da Rocha. Uma vez tendo deixado a Vila do Rio Grande, foi oficial da Câmara em Viamão, logo após a reinstalação desta, em 1766, provavelmente continuidade de um mandato interrompido com "a correria que promoveram os castelhanos” (Prefeitura Municipal..., 1992, p.14). Essa era a única câmara existente no Continente do Rio Grande de São Pedro. Registrou marca de gado nessa mesma Câmara em 1767 (Fortes, 1941, p. 167), e em 1776, morador nos Campos de Viamão, tinha arrolados em sua propriedade, além de sua família, cerca de dezessete escravos (Arquivo Histórico da Cúria..., 1776). Manuel Fernandes Vieira registrou três filhos nos livros de batismo de Rio Grande. A menina mais velha, Vicência, não tem padrinhos registrados, pois seu batismo deu-se em casa, em situação de emergência. Da segunda filha, Clemência, o padrinho é Antônio Lopes da Costa, morador do Rio de Janeiro. Ausente na cerimônia, Lopes da Costa passou procuração para o Capitão de Mar e Guerra ad honorem Mateus Inácio da Silveira, natural da Ilha do Faial, Freguesia de São Salvador, casado com Maria Antônia Silveira, outra das irmãs de Dona Mariana Eufrásia. Mateus Inácio era parente próximo de sua esposa. Por último, o menino Manuel, cujo padrinho foi Anacleto Elias de Afonseca (Jaccottet; Minetti, 2001, p.80), 
Notas sobre a construção de uma "identidade açoriana"...

um dos mais importantes comerciantes da praça do Rio de Janeiro (Fragoso, 1998) e arrematador do contrato dos Registros das Passagens dos Animais de Viamão e Santa Vitória na década de 1770 (Kühn, 2000).

Manuel Bento da Rocha. Não se tem por certo a sua procedência. Provavelmente fora vereador na Vila do Rio Grande, sendo também membro da Câmara em Viamão, após a transferência. Era casado com Dona Isabel Francisca da Silveira, outra das irmãs de Dona Maria Eufrásia e sócio de Manuel Fernandes Vieira no contrato dos Açougues. Em 1755 recebeu carta de sesmaria de uns campos chamados Curral de Arroios, constando neles edificações de casas, plantações das quais já fizera colheitas (Arquivo Público..., 1933, p. 150-152). Na nova freguesia do Triunfo, possuía terras em sociedade com Francisco Pires Casado, com os já citados numerosos animais (Arquivo Histórico do Rio Grande do Sul, cód. F1198-A 1784). Consta ter mais dois rincões, sem sociedade. Nessas terras, possuiria 12.000 vacuns, 4.600 cavalos e éguas, 1160 burros e burras; todavia, estas últimas informações não estão confirmadas (Pawels, 1930, notas 13, 23). Em Rio Grande, foi padrinho de mais quatro crianças, além do filho de Francisco Pires Casado, seu sócio em terras e cunhado. Seus afilhados são filhos de gente provinda das ilhas de São Jorge, Graciosa, Pico e Faial, entre os quais uma das filhas do também já citado Capitão de Mar e Guerra ad honorem Mateus Inácio da Silveira (Jaccottet; Minetti, 2002, p. 90). Entre os anos de 1766 e 1775, estão registrados cinco óbitos de escravos seus em Viamão (Neumann, Kühn, prelo) ainda que não se tenham encontrado outros registros de sua escravaria.

Domingos de Lima Veiga. Natural da Península, casado com Gertrudes Pais de Araújo. Segundo Queiroz, possuía no mínimo entre cinco e sete escravos na Vila do Rio Grande. Deteve patente de Sargento, Alferes da Cavalaria de Ordenança e de Capitão da Ordenança do Rio Grande, foi oficial da Câmara em 
Viamão, em 1767 (Prefeitura Municipal..., 1992, p.14) e escrivão da Fazenda Real na década de 1770. Na vila do Rio Grande, foi padrinho de oito crianças açorianas, o que conota o seu prestígio entre os ilhéus. Muito mais se visto que sua família - esposa e filhos - era constantemente convidada ao compadrio, ainda que não houvesse grande concentração de afilhados em quaisquer de seus membros. Domingos de Lima Veiga é o único dos padrinhos dos filhos de Francisco Pires Casado que não pertencia à família, mas não deixava de pertencer ao pequeno "clube" de detentores de escravos, terras, patentes e privilégios na Vila do Rio Grande. A assinatura de Domingos de Lima Veiga aparece num grande número de documentos de datas de terras entregues aos açorianos, e coincidentemente, sua família, quando ainda era moradora de Rio Grande, foi uma das que mais apadrinhou filhos de migrantes ilhéus. Isso aponta para uma estreita relação entre a "popularidade" daqueles que são amiúde convidados para padrinhos e a existência de uma base social de apoio que dê sustento às posições de mando em uma localidade (Hameister, 2003a). Também aponta para a existência de uma via de duas mãos: de alguma forma, o Capitão participou da aplicação da justiça distributiva quando fez medir e assegurar as terras a seus compadres e afilhados ilhéus ou descendentes, retornando a eles a dádiva inicial de ser incluído em suas famílias por meio de um parentesco religioso e espiritual.

Retornando aos batismos do genro de Antônio Furtado de Mendonça, tem-se que, entre Francisco Pires Casado, seus parentes, seus compadres ou cunhados, encontram-se, no mínimo, as seguintes mercês, cargos, patentes, escravos, terras e animais, concomitantemente ou dispersas ao longo de suas trajetórias:

a) quatro marcas de gado;

b) uma patente de Capitão-de-Mar e Guerra ad honorem, uma de Sargento-Supra da Ordenança, duas patentes de Sargento das Ordenanças, três patentes de Capitão das Ordenanças e duas patentes de Alferes das Ordenanças;

Anos 90, Porto Alegre, v. 12, n. 21/22, p.53-101, jan./dez. 2005

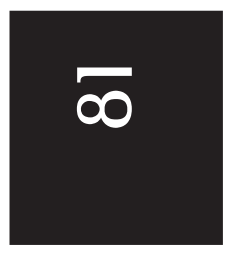


Notas sobre a construção de uma "identidade açoriana"...

c) três vereadores;

d) quatro sesmarias;

e) 41 escravos

f) 20.000 cabeças de gado vacum; 5.000 cavalos, 1.200 asininos;

g) ofício de Tabelião da Vila do Rio Grande, ofício de Escrivão do Juizado de Órfãos, ofício de escrivão da Fazenda Real;

h) contrato dos Açougues.

Outras comprovações do estatuto social elevado dessas famílias podem ser observadas na qualidade dos dotes quando do casamento de suas filhas, que estão sendo estudados por Fábio Kühn (2003).

Não há como dizer que a família derivada de Antônio Furtado de Mendonça se igualava, na pobreza e na necessidade, com os demais insulanos. Observando a qualidade dos compadres de Francisco Pires Casado e dos compadres de seus cunhados, vê-se que jamais convidaram ao compadrio alguém em situação inferior à sua. Todos os compadres de Francisco Pires Casado detinham bens, cargos e privilégios suficientes para inseri-los nos altos escalões da pirâmide social do Continente do Rio Grande de São Pedro. Francisco Pires Casado e seus familiares, cientes de sua posição na sociedade, não abriam as portas das relações mais próximas com sua família às outras famílias que não detinham posição semelhante à sua.

Importante registrar que, salvo os registros de batismo, nos quais as "Ilhas" são mencionadas de forma genérica ou com seu nome próprio, elas aparecem apenas como local de origem dos pais, padrinhos ou avós das crianças, não se localizou nenhum outro registro documental no qual Francisco Pires Casado ou qualquer um de seus compadres ou familiares que de lá viessem, que alegassem ser "gente das Ilhas", ou pertencerem aos "casais de Sua Majestade". As terras que dispunham não lhes foram dadas como datas de Casais. Foram doadas na década de 1750, durante a 
distribuição de sesmarias promovida por Gomes Freire de Andrade em sua expedição de demarcação de limites do Tratado de Madri (Arquivo Público..., 1929, 1933) ou adquiridas por compra. Tampouco suas terras se comparavam a essas datas de casais em dimensões.

Disso é possível antever que, nem eles, nem a sociedade na qual viviam os percebiam como "gente das Ilhas", aqueles que durante vinte ou mais anos aglutinaram-se em torno da reivindicação comum: receber as terras e incentivos prometidos quando de

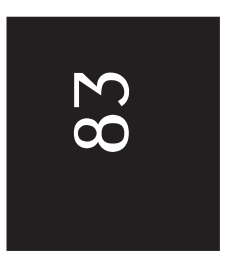
sua partida das Ilhas. No conjunto das relações mais próximas de Francisco Pires Casado, portanto, encontramos muitas pessoas nascidas nos Açores, com toda a certeza, mas não que compartilhavam da "identidade açoriana" que se forjou no Continente do Rio Grande de São Pedro. Essa "identidade", tudo leva a crer, tinha como agente aglutinante insistência em fazer cumprir os termos do Edital de 1747, que prometia aos Casais de Sua Majestade terras, insumos e auxílios. Não é, então, essa identidade prerrogativa do local de origem e sim fruto de um processo histórico do qual algumas famílias participaram e outras abdicaram de sua inclusão no grupo.

Se os homens e mulheres da família de Antônio Furtado de Mendonça não eram "açorianos" na acepção de desinência de uma identidade, resta perguntar quem o era e por que o era. Assim como cabe também perguntar o porquê de as filhas e genros de Antônio Furtado de Mendonça não o serem. O caso dos migrantes ilhéus para o Estado do Grão-Pará e Maranhão pode vir a trazer alguma luz sobre esse problema.

\section{Açoriano: "ser ou não ser, eis a questão"}

$\mathrm{Na}$ seção anterior, foi visto que nem todos os que migraram padeciam da mesma sorte. A alegada "pobreza" de Berenger e 
Notas sobre a construção de uma "identidade açoriana"...

Bitencourt, que possuía um ou dois morgados em sua família, nem de longe se compara à perspectiva de fome pela qual passavam os agricultores não proprietários ou a gente de ofício, pertencentes aos estratos livres mais baixos da sociedade insulana. Como já visto, a pressão demográfica que existia nas ilhas apresentava duas faces específicas: uma para os estratos subalternos e outra para os bem nascidos, mas que, todavia, não eram os primogênitos.

Entretanto, como sói acontecer nas sociedades de Antigo Regime, os mais aquinhoados eram uma minoria, uma parcela diminuta da sociedade. Os arquipélagos dos Açores e da Madeira não eram exceção dentro da sociedade portuguesa (Vieira, 1992). Isso significa que a maioria dos migrantes também era oriunda desses estratos inferiores da sociedade. Eram famílias de agricultores sem terras, em sua maioria, e alguns artesãos.

Os membros dos estratos inferiores também engajavam-se, voluntariamente ou não, nas tropas de Sua Majestade, podendo vir a servir em qualquer ponto do Império Português, fosse na América, na África ou na Ásia. Isso lhes dava uma possibilidade de ascensão social, por meio das promoções por mérito e, também, do uso da farda, o que os punha a certa distância de um mundo majoritariamente camponês. Muitos desses soldados oriundos das Ilhas chegaram ao Continente do Rio Grande de São Pedro antes da migração em massa das famílias dos Açores. Conforme o Parecer do Conselho Ultramarino assinado por Alexandre de Gusmão e um despacho real ordenando o embarque de soldados (Cortesão, 1951, p.442-443), chegaram ao extremo-sul nessa condição, ficando claro que não faziam parte dos "Casais de Sua Majestade". Mas, dependendo das opções que se abriram a eles, não se escusaram de tentar tornar-se membros dos casais, principalmente por intermédio do casamento com moças ou viúvas vindas dos Açores. Verificam-se, também, soldados e civis que, não tendo relação alguma com os Açores, buscaram, via alianças matrimoniais, seu ingresso nesse grupo de migrantes, com seus filhos

Anos 90, Porto Alegre, v. 12, n. 21/22, p.53-101, jan./dez. 2005 
passando a ser identificados como "gente das Ilhas". Isso é perceptível nas solicitações de "não-açorianos" nas cartas de datas de terras passadas aos que se reivindicavam do direito de recebê-las a partir dos termos do Edital de 1747 e adendos posteriores (Barroso; Brochado; Tassoni, 2002).

Existe, portanto, uma série de intentos distintos, fazendo parte de um mesmo grande fenômeno: nativos dos Açores que não se identificam como "das Ilhas"; nativos dos Açores que faziam questão de serem identificados como "das Ilhas"; gente que jamais havia posto os pés nas Ilhas, ocupada em juntar-se às gentes "das Ilhas". Resta entender esses fenômenos e tentar explicar por que eles ocorriam.

Busca-se, pois, comparação com o caso estudado por Acevedo Marin (2002) para os ilhéus que migraram para o Estado do Grão-Pará e Maranhão no mesmo período em que migraram também para o extremo-sul do Estado do Brasil. Acevedo Marin destaca a Vila de São José de Macapá, uma povoação levada a cabo, principalmente, por nativos das Ilhas. Em uma outra localidade, com diferentes especificidades, essa comparação pode trazer luz à sorte de fenômenos que aconteceram no sul e, talvez, auxilie na explicação para a acentuada diferença entre esses dois procedimentos nas fronteiras americanas do Império Português.

Segundo essa autora, os açorianos migrados na década de 1750 experimentaram um processo de decadência pois, ao final de pouco mais de cinqüenta anos, em um arrolamento populacional feito em 1808 no qual também são listadas posses e propriedades, só restavam alguns poucos açorianos. Destes, a imensa maioria achava-se em estado de pobreza. A posse de escravos por parte dos açorianos seria muito pequena em comparação a outros setores, assim como o restante de seus bens. Achou, também, muitas viúvas com sua prole ou poucos agregados, ocupados na execução das funções domésticas, do artesanato e da agricultura. 
Notas sobre a construção de uma "identidade açoriana"...

Os motivos alegados por essa autora para tal decadência dizem ser os açorianos majoritariamente pequenos agricultores e que o Grão-Pará, a este tempo, passava pela inserção de seus produtos naquilo que ela chama de "uma política mercantilista". A produção dessas pequenas propriedades seria escoada e comercializada dentro da política pombalina de incentivo ao desenvolvimento do comércio nessa região. Isso colocaria os ilhéus na dependência da Companbia de Comércio do Pará para a vazão dos grãos e farinhas produzidos, bem como os colocaria como usuários dos créditos cedidos pela mesma Companhia. Por ser a produção diminuta, não teriam podido concorrer no mercado de exportações com os "grandes" da Capitania, tampouco saldar as dívidas oriundas da cessão de créditos. Isso teria corroído a economia que, nos primeiros momentos, dava sinais de prosperidade, mas que com o transcorrer dos anos teria levado à bancarrota os "açorianos" da Vila de São José de Macapá.

Ante os dados colocados pela autora, não é possível duvidar que, passados cinqüenta anos, os "açorianos", ainda que assim não se identificassem, estavam de fato em uma situação pouco favorável. Mas essa parece uma explicação por demais simples para uma situação que, mesmo por meio dos dados fornecidos pela autora, apercebe-se com uma configuração muito mais complexa.

Em primeiro lugar, há o recorrente alerta de que o povoamento dessa fronteira norte foi modificado pela política pombalina. Mas isso também ocorreu no Sul, não sendo esse, portanto, motivo de diferenciação entre as duas distantes regiões. Todavia, fica num segundo plano o fato de que todas as diretrizes pombalinas experimentadas no Norte previam e privilegiavam a inserção das populações autóctones por meio, inclusive, de alianças matrimonias na sociedade de características predominantemente lusas que se formava.

Anos 90, Porto Alegre, v. 12, n. 21/22, p.53-101, jan./dez. 2005 
Durante os anos do Ministério de Pombal, a obtenção de privilégios, mercês, cargos, patentes e terras, assim como honras passava pela integração das populações de origem européia com os indígenas. Ilhéus ou gente de outra procedência entrariam nessa cadeia de prestações e contraprestações de dádivas com a Coroa lusa - o sistema de mercês - principalmente se procedessem alianças com as populações autóctones. O maior incentivo era dado aos que gerassem filhos miscigenados. Essa era a ênfase das diretrizes de Pombal, expressas principalmente na Lei de Liberdades e no Diretório dos Índios (1757). Caso isso não ocorresse, ainda assim poderiam usufruir de algumas benesses reais. Todavia, a prioridade era para aqueles que obtiveram sucesso nessas alianças.

Diferente foi o caso do Continente do Rio Grande de São Pedro, no qual a aplicação da legislação pombalina, como foi visto por Elisa Frühauf Garcia em sua dissertação de mestrado acerca da integração dos indígenas na sociedade sulina, atingiu muito mais as práticas de particulares em sua utilização dos índios como mãode-obra do que apresentando alterações no acesso a privilégios e mercês dados pela Coroa aos que miscigenaram (Garcia, 2003).

Em segundo lugar e corroborando essa idéia, Francisco Xavier de Mendonça Furtado, governador da Capitania e irmão do Marquês de Pombal, quando da chegada das primeiras levas de colonos dos Açores em Belém, em citação feita pela autora, reclama do fato de estarem sendo envidadas muito mais mulheres do que homens (Acevedo Marin, 2002, p. 50). Não se sabe aqui se essas migravam sozinhas ou em famílias. Todavia, esse detalhe pouca diferença faz. O que importa é que, ao contrário do sul, onde os casais com prole numerosa e, mais ainda, aqueles que levavam consigo mulheres acima dos doze anos, eram claramente privilegiados nas ajudas de custo. Havia um plus nessa ajuda: $2 \$ 500$ réis eram dados por cada mulher que se dirigisse para lá, conforme o Edital de 1747 (Fortes, 1999, p. 26-27). Isso porque, conforme visto anteriormente, o extremo-sul necessitava de mulheres para 
Notas sobre a construção de uma "identidade açoriana"...

estabelecer famílias com os soldados e demais povoadores. Desejavam que essas famílias, juntamente com a promessa de terras e insumos, servissem de âncora aos povoadores.

A ajuda de custo extra oferecida aos "açorianos" do extremo norte era, inicialmente, em maio de 1751 , de $2 \$ 400$ réis pelas mulheres desimpedidas entre 12 e 25 anos, à semelhança do que fora oferecido para o Rio Grade e Santa Catarina, não sendo oferecido nenhum plus aos homens, conforme se lê na Carta de D. José I para o Governador do Maranhão-Pará, participando a próxima ida de 1.000 casais açorianos para o Pará, datada de 13 de maio de 1751 (Cortesão, 1951). Entretanto, por algum motivo, em dezembro de 1751 passou a haver uma diferença na ajuda de custos efetivamente dada, em favor dos homens. Passou para um tostão para cada homem e dois vinténs para cada mulher. Ou seja, ao contrário do sul, as mulheres lusas eram pouco "valorizadas" nesse povoamento, haja vista que recebiam ajuda menor que a dos homens. Além, é claro, da reclamação de que estavam indo muitas mulheres nas embarcações.

Disso depreende-se que, ao contrário do extremo-sul, o extremo-norte não tinha um desequilíbrio na relação entre os sexos, com diferença favorável ao setor masculino luso na formação dos povoados. Tudo induz a pensar que, ao contrário, no extremonorte, havia oferta de mulheres o bastante para que casamentos fossem realizados e que a procriação dos colonizadores ocorresse. Ora, é recorrente na historiografia e na documentação colonial que, ao iniciar um povoamento, principalmente em áreas de fronteira aberta, dada a necessidade de conquista bélica ou de defesa militar dos territórios, o contingente masculino seja mais numeroso e as mulheres pouco dispostas a irem para esses locais ermos, violentos e instáveis. José da Silva Pais recorreu, inclusive, às tais mozuelas, já que os soldados, se casados, raramente conduziam às fronteiras as suas esposas e filhas.

Anos 90, Porto Alegre, v. 12, n. 21/22, p.53-101, jan./dez. 2005 
Se as mulheres européias não eram bem-vindas na região do Pará, significa dizer que havia mulheres em abundância para proceder ao povoamento, oriundas dos inúmeros grupamentos e aldeias indígenas existentes na região. Não parece por acaso que Francisco Xavier de Mendonça Furtado tenha aconselhado que as novas povoações ficassem intercaladas entre duas aldeias indígenas, fossem elas autônomas, fossem elas geridas pelos padres da Companhia de Jesus (Acevedo Marin, 2002).

Também aos colonos ilhéus, com alegação de evitar a nociva

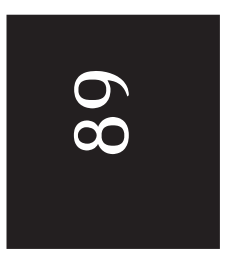
ociosidade, era recomendado que trabalhassem a terra com as próprias mãos. ${ }^{12}$ Isso os colocava distantes da possibilidade de ter concessão, estatal ou dos padres da Companhia, para explorar a mão-de-obra indígena como os demais povoadores podiam fazer. Necessitavam, assim, para ter acesso a essa mão-de-obra ainda abundante na região, a formação de alianças com os autóctones. O casamento com as índias, mais do que uma mulher e uma prole, significava formar uma família nesse meio, possuir cunhados, adentrar nas cadeias de reciprocidade das populações indígenas. Muitas destas, tradicionalmente, trabalhavam em mutirão. A obtenção de tal força de trabalho, portanto, passava por alianças. Destas, as alianças matrimoniais eram mais fáceis de serem obtidas do que acordos negociados. Essas alianças eram estimuladas pela Coroa e recompensadas com mercês e privilégios (Diretório dos Índios, 1757).

Para que com esses casamentos miscigenados fosse obtido sucesso, a identidade de "gente das Ilhas" deveria desaparecer. Deveriam esses ilhéus, e principalmente sua prole, tornar-se tão nativos quanto os nativos. Para obter o acesso aos recursos locais, a abdicação de uma identidade de "gente das Ilhas" se fez necessária, assim como a construção de uma nova identidade, consoante com os estímulos régios e às possibilidades de formação de alianças com as populações locais. Casos como esse, de formação de uma identidade e de padrões sociais e culturais associados ao acesso

Anos 90, Porto Alegre, v. 12, n. 21/22, p.53-101, jan./dez. 2005 
Notas sobre a construção de uma "identidade açoriana"...

a recursos foram estudados e discutidos por Fredrik Barth, cujas conclusões e indicações auxiliam no entendimento do tema aqui abordado (Barth, 1961, 1980 [1959], 1981; 2000). No entanto, diz uma carta do Governador do Grão-Pará para o Conselheiro do Ultramarino Diogo de Mendonça Corte Real, datada de 1752, referindo-se a São José de Macapá:

A mim me parecia que com o grande estabelecimento que tem a podia Sua Majestade fazer cidade, porque de primeiros povoadores há de ter perto de $\mathbf{6 0 0}$ pessoas brancas que, certamente, sem mescla, não as tem nenhuma deste Estado [...]. (apud Mendonça, 1963, v. 1, p. 210).

Se, em 1752, a população da localidade era branca e sem mesclas, muito possivelmente assim ainda o era em 1757, quando foi instituído o Diretório dos Índios, ou seja, quando passou a vigorar a legislação que premiava e concedia mercês às populações com mescla. Os recursos econômicos e políticos, portanto, a serem conferidos com base no Diretório, passaram longe da população branca - os nativos das Ilhas e seus descendentes - de São José de Macapá. Sem grandes porções de terras, sem a farta mãode-obra indígena, de fato, parece muito lógico e provável que não prosperassem.

$\mathrm{Na}$ referida listagem de 1808, Acevedo Marin destaca a quantidade de viúvas açorianas, também empobrecidas e que lavravam a terra com o auxílio da mão-de-obra familiar e/ou poucos agregados e menos ainda com escravos. Ao que parece, "açorianas", e mais especialmente as "viúvas açorianas" no extremo-norte possuíam "pouco valor" no mercado matrimonial da região. Isso também contrasta com a situação do extremo-sul. No norte, elas não representavam um "passaporte" para uma data de terras. Essas doações régias estavam reservadas ou, ao menos, eram dadas com mais freqüência, às famílias que geraram prole miscigenada e, com isso, aproximaram grupos indígenas da sociedade portuguesa no

Anos 90, Porto Alegre, v. 12, n. 21/22, p.53-101, jan./dez. 2005 
Martha Daisson Hameister

Estado do Grão-Pará e Maranhão. Parece que um segundo casamento a essas mulheres não era uma possibilidade posta ao dia. De forma antagônica, encontram-se registrados nas datas de terras do Rio Grande de São Pedro alguns homens que não procediam dos Açores e solicitavam uma porção de terras por serem casados com "viúva de casal". Também são recorrentes os pedidos de terra para homens casados com "filhas de casal" ou "agregadas de casal" (Barroso; Brochado; Tassoni, 2002). Isso ressalta o "valor" dessas "açorianas" em uma escolha matrimonial no extremo-sul.

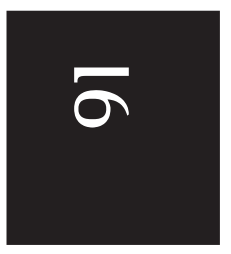
Por meio do matrimônio com alguma delas, homens viram-se habilitados a uma mercê régia, sob forma de terras e outros incentivos.

Em outras palavras, não é surpreendente que, em São José de Macapá, um povoado formado essencialmente por "açorianos", ao cabo de cinqüenta anos estes não mais existissem como setor mais abastado da população paraense. Mais ainda, os que reivindicavam a identidade "açoriana" ou "gente das Ilhas", ao que parece, investiram em uma estratégia que se revelou equivocada na obtenção de terras, mão-de-obra, privilégios, patentes, distinções e honras. Nessa porção da América Portuguesa, a ênfase ao acesso de recursos era, antes de mais nada, oferecida àqueles que povoaram de acordo com as orientações do Diretório dos Índios (1757).

Retornando ao extremo-sul, verifica-se, portanto, que o acesso aos recursos, ao contrário do extremo-norte, tinha como ênfase a ligação com gente dos "casais" ou "das Ilhas". Assim reza o Edital de 1747 e seus posteriores adendos. As populações recém chegadas das Ilhas a partir 1749 deveriam, portanto, manter-se como "gente das Ilhas" até um matrimônio dado no prazo de, no máximo, cinco anos, assim diziam as ordens. Este item, num primeiro momento, atingia apenas os "filhos dos casais". Posteriormente foi estendido aos "agregados dos casais". Houve uma demora de aproximadamente vinte anos, até o início da década de 1770, para o início da distribuição de terras. O retardo foi provocado, num

Anos 90, Porto Alegre, v. 12, n. 21/22, p.53-101, jan./dez. 2005 
Notas sobre a construção de uma "identidade açoriana"...

primeiro momento, pela impossibilidade de serem assentados os colonos nas terras pertencentes às Missões dos padres espanhóis, cujos índios levantaram-se no episódio denominado na historiografia como Guerras Guaraniticas. Num segundo momento, complicaram-se ainda mais, dada a invasão da Vila do Rio Grande pelos espanhóis e perda de boa parte do Continente do Rio Grande para os castelhanos. O prazo para que os "Casais", "filhos de Casais", os "casados com filhos de Casais", os "agregados de Casais", os "casados com agregados de Casais", os casados com "viúvas de Casais" requeressem a terra e os incentivos foi dilatado quase que ad infinitum.

Por outro lado, nos documentos de registro das datas de terras conferidas a partir de 1770 e que contemplaram um grande número de imigrantes dos Açores, entre outros outorgados, não se encontrou nenhuma reivindicação vinda de alguém que alegava ser casado com índia, ter filho com índia ou descender de índios. Encontram-se veteranos das campanhas militares, moradores antigos reivindicando a terra por compra que haviam feito ou herança que haviam recebido com intuito de legalizar a posse. Mas não há nenhuma alegação, nos mais de 600 registros vistos, de laços familiares com indígenas. Isso não quer dizer, de forma alguma, que essas uniões mistas não ocorressem. Prole natural ou legítima de brancos e indígenas não são raras nos registros de batismo da Vila do Rio Grande ou de Viamão. Todavia, o que se percebe é que a ênfase à distribuição de recursos do extremo-sul passou ao largo do Diretório dos Índios, sendo privilegiados os termos do Edital de 1747 e seus adendos posteriores. Muito provavelmente por terem os nativos das Ilhas conseguido uma aglutinação e uma geração de identidade. Conseguiram forjar elementos de pertença a um grupo com interesses comuns e que, como tal, de alguma forma, pressionava as autoridades no sentido de fazer cumprir os termos do Edital. 
Novamente, retoma-se a discussão acerca de estratégias. Se foi visto que dentro de um mesmo grupo de origem pessoas ou famílias podiam fazer a escolha de não-inclusão em um grupo identitário, o caso paraense demonstra que aqueles que insistiram em manter a sua "identidade" pregressa foram malfadados. Assim, há que se pensar estratégias, no plural, quando se remete a essa construção ou abdicação de identidades. Também há que se entender estratégias como fruto de uma relação de um grupo social com o restante da sociedade. Ou seja, pode-se investir em uma determinada direção, com intuito de obtenção de uma melhor vida, mas o resultado não é perfeitamente previsível, pois depende de coisas sobre as quais nem sempre esses agentes sociais possuíam o controle. As escolhas, condicionadas pelo meio, não possuem um resultado matematicamente calculado, havendo sempre lugar para que o imprevisto e o acaso interfiram.

\section{Considerações finais}

Essa identidade de "gente das Ilhas" forjada e sustentada no Continente do Rio Grande de São Pedro foi estendida por esses vinte anos e mais além, haja vista ainda em 1800 estarem sendo concedidas as tais datas de terras aos "Casais de Sua Majestade", sua descendência e seus agregados. O Diretório dos Índios, ainda que aplicado em outros territórios luso-brasileiros após seu "teste" no Estado do Grão-Pará e Maranhão, não teve impacto semelhante no extremo-sul, conforme é percebido no trabalho de Garcia (2003). Não foi encontrado nas solicitações de sesmarias, tampouco nas datas de terras de um quarto de légua cedidas aos colonos, homem algum que se alegasse habilitado a uma mercê por ter se casado com índia ou por ser filho de europeu com índia. Isso porque a ênfase para a distribuição dos recursos fora dada ou, antes, conquistada por meio da aglutinação de ilhéus em torno

Anos 90, Porto Alegre, v. 12, n. 21/22, p.53-101, jan./dez. 2005 
Notas sobre a construção de uma "identidade açoriana"...

de seus anseios comuns - o cumprimento dos itens que os favoreciam no Edital de 1747.

A geração da identidade "açoriana" foi, assim, estritamente ligada aos motivos bastante objetivos que não são exclusivos dos açorianos, mas característica comum a toda a humanidade: ter acesso a recursos lhes garantiriam a sobrevivência. A identidade "miscigenada", por não ter sido privilegiada ou por não ter mobilizado os colonos em conquistar os direitos previstos no Diretório dos Índios no extremo-sul, não foi "construída". Ou ainda, se nessas famílias miscigenadas houvesse um componente açoriano, este sim, por motivos estratégicos, era destacado como desinência identitária. Logo, as estratégias vinculadas à geração de uma identidade como a das "gentes das ilhas" ou como a de "mestiços" de sangue europeu e indígena, são fruto de processos históricos, somente possíveis em dadas localidades e regiões. Fazem parte do universo de escolhas possíveis a essa população.

Fica claro, então, na comparação entre os casos do Norte e do Sul, que a permanência e o fortalecimento da desinência "casal de Sua Majestade" ou outros de seus sinônimos, no caso sulino, resultou de uma opção racional. Opção essa condicionada pela necessidade de acesso a recursos que lhes permitissem a sobrevivência ou uma vida melhor. Condicionada pelo meio social em que se deu. Associa-se, assim, à noção de estratégia, aos atos desse grupo que construiu e manteve uma identidade como recurso de sobrevivência. Essa noção, muito cara aos micro-historiadores e, em particular, a Giovanni Levi, numa apropriação do trabalho do antropólogo Fredrik Barth, surge em oposição à noção de estratégia como concernente a

[...] um agente livre e perfeitamente racional que escolhe a partir de um conhecimento perfeito das regras do jogo e de suas conseqüências, tendo a mão todos os recursos necessários para tanto. Em contraposição a esse "homo economicus" - que era o modelo do indivíduo da econo-

Anos 90, Porto Alegre, v. 12, n. 21/22, p.53-101, jan./dez. 2005 
Martha Daisson Hameister

mia clássica - o que o modelo de Barth colocava em cena era um ator que deveria agir dentro de uma sociedade (qualquer sociedade onde os recursos materiais, culturais e cognitivos disponíveis eram distribuídos de modo desigual. Um indivíduo racional, certamente, mas não dotado de uma "racionalidade absoluta: ao contrário, o que se propõe é um indivíduo que age - nas palavras de Levi - a partir de uma "racionalidade limitada", isto é, a partir dos recursos limitados que o seu lugar na trama social lhe confere, em contextos onde sua ação depende da interação com as ações alheias, e onde, portanto, o controle sobre o seu resultado é limitado por um horizonte de constante incerteza. (Lima Filho, 1999, p. 259-260. Grifos do autor).

Tanto no Sul como no Norte, a construção de identidades seguiu critérios racionais, práticos e objetivos na vida dessas pessoas. As estratégias para vida e sobrevida nos territórios americanos, crê-se aqui, comandaram esse espetáculo de formação de identidades ou abdicação das mesmas no processo de colonização.

\section{Notes on construction of an "Azorean identity" in the Southern Brazil colonization in $\mathrm{XVIII}^{\text {th }}$}

Abstract. This paper aimes to contributing to the debate on the making of an "Azorean identity" during the process of conquest and colonization of Brazil's southern lands. Seen as a cohesive and homogeneous group, the "Azoreans" - as they are called in southern historiography - would also have, according to that historiography, a homogeneous behavior resulting from their common origin in the Islands. However, the purpose here is to demonstrate that the group's identification and identity are above all a result of particularly southern traits as well as options and strategies employed by those migrants in the far south of the State of Brazil, with no correlate in the State of Grão-Pará and Maranhão, where a similar number of islanders were transferred to during the same period. Therefore, it is argued that such identity has been historically built along conquest and peopling of the south. Evidence of such phenomenon and some of its possible causes are pointed out.

Keywords: Azorean migration. Social strategies. Family strategies. Colonial Rio Grande do Sul.

Anos 90, Porto Alegre, v. 12, n. 21/22, p.53-101, jan./dez. 2005 
Notas sobre a construção de uma "identidade açoriana"...

\section{Notas}

${ }^{1}$ Agradeço a Vanessa Gomes de Campos, historiógrafa do Arquivo Histórico da Cúria Metropolitana de Porto Alegre, a cessão de seu material de pesquisa e transcrições referentes ao Treslado do Rol dos Confessados de Triunfo, dos Róis de Confessados de Viamão e dos Autos de Justificação de Matrimônio da mesma localidade. Agradeço aos professores Fábio Kühn e Eduardo Neumann a cessão de documentação transcrita referente aos registros de óbitos e batismos de Viamão e Porto Alegre, parte integrante do Projeto Resgate de Fontes Paroquiais - Porto Alegre e Viamão, século XVIII, por eles coordenado, com apoio de FAPERGS - PROPESQ/UFRGS, ainda no prelo. Agradeço à acadêmica Tatiana Carrilho Pastorini o auxílio prestado na digitalização das fontes paroquiais sob guarda da Diocese Pastoral de Rio Grande e, nesta Diocese, agradeço o prestimoso auxílio de Iara e Dulci, do Senhor Leopoldo e do Bispo de Rio Grande, Dom Luís Mário, que me franquearam o acesso ao acervo e auxiliaram-me em minhas buscas. Agradeço a Roberto Cataldo Costa a versão do resumo para o inglês, e a Jorge Pontual Waked e Taís Campelo Lucas a leitura, a revisão e as sugestões. Todos contribuíram, estando, porém, redimidos da responsabilidade sobre resultado final. Esta compete apenas a mim.

${ }^{2}$ Uma versão anterior deste trabalho foi apresentada em um evento promovido pela Associação Brasileira de Pesquisadores em História Econômica, e seu texto foi publicado em anais (Hameister, 2004).

${ }^{3}$ Extrato das notícias que em uma Carta escreveu José da Silva Pais ao Prior de Chaves, Duarte Pereira Chaves - provavelmente de 1742 (Cesar, 1969, p. 128).

${ }^{4}$ Junta: termo sobre a expedição (Mendonça, 1989, p.171).

${ }^{5}$ Parecer do Conselho Ultramarino e despacho, março e abril de 1744 (Cortesão, 1951, p. 440-441).

${ }^{6}$ Carta de D. João III a Pedro Anes do Canto (Cortesão, 1951, p. 395-397).

${ }^{7}$ Requerimento de Henrique Cesar Berenger e Bitencourt natural da Ilha da Madeira e um dos povoadores da Ilha de Santa Catarina datado de 1750 e anexos (Anais da Biblioteca Nacional, v. 50, p. 83-85, 1936. Disponível em: <http://www.bn.br/fbn/ bibsemfronteiras/>. Acesso em: nov. 2004.

${ }^{8}$ Consulta do Conselho Ultramarino, anexa ao Requerimento de Henrique Cesar Berenger e Bitencourt, 1750. (Anais da Biblioteca Nacional, v. 50, p.84, 1936).

${ }^{9}$ Requerimento de Henrique Cesar Berenger e Bitencourt, natural da Ilha da Madeira e um dos povoadores da Ilha de Santa Catarina, 1750 (Anais da Biblioteca Nacional, v. 50, p.83-85, 1936).

${ }^{10}$ Idem, ibidem.

${ }^{11}$ Anexo ao Requerimento de Henrique Cesar Berenger e Bitencourt.... (Anais da Biblioteca Nacional, v. 50, p. 84-85, 1936.

Anos 90, Porto Alegre, v. 12, n. 21/22, p.53-101, jan./dez. 2005 


\section{Martha Daisson Hameister}

${ }^{12}$ Instrução que levou o Capitão-mor João Batista de Oliveira... (Mendonça, 1963, v. 1, p. 116).

\section{Referências}

ACEVEDO MARIN, Rosa Elizabeth. Açorianos nas terras conquistadas pelos portugueses no Vale do Amazonas: açorianos no Cabo Norte - século XVII. In: BARROSO, Véra Lucia Maciel. Açorianos no Brasil. Porto Alegre: EST, 2002.

ALMEIDA, Cândido Mendes de. Código Pbilipino. Rio de Janeiro: Typografia do Instituto Philomantico, 1870. Disponível em: <http://www.uc.pt/ihti/proj/ filipinas/L2P454.HTM>. Acesso em: nov. 2004.

ARQUIVO PÚBLICO MINEIRO. Demarcação do Sul do Brasil. Revista do Arquivo Público Mineiro, Belo Horizonte, Imprensa Oficial, v. XXIII, n. 1, 1929.

Demarcação do Sul do Brasil. Revista do Arquivo Público Mineiro, Belo Horizonte, Imprensa Oficial, v. XXIV, n.1,1933.

BARROSO, Véra Lucia Maciel. Açorianos no Brasil. Porto Alegre: EST, 2002.

BARROSO, Véra Lucia Maciel; BROCHADO, Suzana S.; TASSONI, Tatiani de Souza. Açorianos, proprietários de terras no Rio Grande do Sul 1770-1800 (Documentos Interessantes do Arquivo Histórico do Rio Grande do Sul códices F1229, F1230, F1231). In: BARROSO, Véra Lucia Maciel. Açorianos no Brasil. Porto Alegre: EST, 2002.

BARTH, Fredrik. Nomads of South Persia; the basseri tribe of Khamseh confederacy. Boston: Litle, Brown \& Company, 1961.

The political leadreship among Swat Pathans. 19. Nova York: Athlone Press; Humanities Press Inc., 1980 [1959].

Process and form in social life. Selected essays of Fredrik Barth. Londres; Boston; Henley: Routledge \& Kegan Paul, 1981. v. 1.

Os grupos étnicos e suas fronteiras. In: BARTH, Fredrik. O guru, o iniciador e outras variacõos antropológicas. Rio de Janeiro: Contra Capa Livraria, 2000.

CESAR, Guilhermino. Os primeiros cronistas do Rio Grande do Sul; 1605-1891. Porto Alegre: Editora da UFRGS, 1969.

Anos 90, Porto Alegre, v. 12, n. 21/22, p.53-101, jan./dez. 2005 
Notas sobre a construção de uma "identidade açoriana"...

COMISSOLI, Adriano. Casais de Sua Majestade que vão para as missões: a migração açoriana nos Campos de Viamão. 2002. (Monografia) - Departamento de História, Instituto de Filosofia e Ciências Humanas, Universidade Federal do Rio Grande do Sul, Porto Alegre, 2002.

CORTESÃO, Jaime. Alexandre de Gusmão e o Tratado de Madri; antecedentes do Tratado. Documentos organizados e anotados por Jaime Cortesão. Rio de Janeiro: Ministério das Relações Exteriores; Instituto Rio Branco, 1951.

COUTINHO, André Ribeiro. Memória dos serviços prestados pelo Mestre-de-Campo André Ribeiro Coutinho no Governo do Rio Grande de São Pedro, dirigida a Gomes Freire de Andrade - 1740. Bibliovirt/Liphis, 2002. Disponível em: <www.liphis.com/ bibliovirtual/ribeirocoutinho.pdf>. Acesso em: jan. 2004.

D. JOSÉ I. Diretório que se deve observar nas Povoações dos Índios do Pará, e Maranhão, enquanto Sua Majestade não mandar o contrário. 1757. Disponível em: <http:// fusaoracial.netfirms.com/Diretorio_Pombal_integral.htm>. Acesso em: nov. 2004.

FORTES, João Borges. Rio Grande de São Pedro; povoamento e conquista. Rio de Janeiro: Ministério da Guerra/Biblioteca Militar, 1941. Erus, 1980.

O Brigadeiro José da Silva Paes e a fundação do Rio Grande. Porto Alegre:

Os casais açorianos; presença lusa na formação sul-rio-grandense. Porto Alegre: Martins Livreiro, 1999.

FRAGOSO, João. Homens de grossa aventura; acumulação e hierarquia na praça mercantil do Rio de Janeiro 1790 - 1830. Rio de Janeiro: Civilização Brasileira, 1998.

Afogando em nomes: temas e experiências em história econômica. TOPOI, Revista de História do Programa de Pós-graduação em História Social da UFRJ, n.5, 2002.

GARCIA, Elisa Frühauf. A integração das populações indígenas nos povoados coloniais no Rio Grande de São Pedro: legislação, etnicidade e trabalho. 2003. Dissertação (Mestrado) - Programa de Pós-Graduação em História Social, UFF, Niterói, 2003.

GINZBURG, Carlo. O nome e o como: troca desigual e mercado historiográfico. In: _. A micro-bistória e outros ensaios. Lisboa; Rio de Janeiro: DIFEL; Bertrand Brasil, 1989.

Anos 90, Porto Alegre, v. 12, n. 21/22, p.53-101, jan./dez. 2005 
Martha Daisson Hameister

GRAEBIN, Cleusa Maria Gomes. Sonhos, Desilusões e Formas Provisórias de Existência: os açorianos no Rio Grande de São Pedro. 2004. Tese (Doutorado) Universidade do Vale do Rio dos Sinos, São Leopoldo, 2004.

HAMEISTER, Martha Daisson. O Continente do Rio Grande de São Pedro; os homens, suas redes de relações e suas mercadorias semoventes (c.1727-c.1763). 2002. Dissertação (Mestrado) - Universidade Federal do Rio de Janeiro, Rio de Janeiro, 2002. Disponível em: <http://www.liphis.com/teses/pt/ dissert_MarthaDaissonHameister.pdf>. Acesso em: set. 2004.

Na pia batismal: estratégias de interação, inserção e exclusão social entre os migrantes açorianos e a população estabelecida na Vila do Rio Grande através do estudo das relações de compadrio e parentescos fictícios (1738-1763). In: CONGRESSO BRASILEIRO DE HISTÓRIA ECONÔMICA, V, CONFERÊNCIA INTERNACIONAL DE HISTÓRIA DE EMPRESAS, 6., 10 ANOS DE ABEPH. Anais... Caxambu: ABPHE, 2003a. Disponível em: <http://www.abphe.org.br/congresso2003/Textos/Abphe_2003_91.pdf>. Acesso em: nov. 2004.

O segredo do pajé; o nome como um bem (Continente do Rio Grande de São Pedro, c. 1735-c.1777). Texto de trabalho. Rio de Janeiro, 2003 b.

A identidade "açoriana": os Casais de Sua Majestade na colonização da América Portuguesa ao século XVIII. In: ENCONTRO DA PÓS-

GRADUAÇÃO EM HISTÓRIA ECONÔMICA, II. Anais... Niterói: ABPHE/ UFF, 2004. 1 CD Rom.

JACCOTTET, Alda Maria de Moraes; MINETTI, Raquel Domingues de. Diáspora açoriana; açorianos na Vila de Rio Grande de São Pedro antes da invasão espanhola - Livros 1,2,3 e 4 de Batismos (1738-1763) 1 de Casamentos (17561763) e 1 de Óbitos (1738-1763). Pelotas: edição das autoras, 2001.

KÜHN, Fábio. A redescoberta da fronteira; os Campos de Viamão e o povoamento do extremo sul do Brasil colonial - século XVIII. 2000.

A prática do Dom: família, dote e sucessão na fronteira da América Portuguesa. In: JORNADA SETECENTISTA, V, Curitiba, 2003. Anais... Curitiba, 2003. Disponível em: <http://www.humanas.ufpr.br/ departamentos/dehis/cedope/atas/fabio_k\% $\%$ FChn.pdf $>$. Acesso em: nov. 2004.

Anos 90, Porto Alegre, v. 12, n. 21/22, p.53-101, jan./dez. 2005 
Notas sobre a construção de uma "identidade açoriana"...

LEVI, Giovanni. Reciprocidad mediterránea. Tiempos Modernos: Revista Electrónica de Historia Moderna, n. 7, 2002. Disponível em: < http://

www.tiemposmodernos.org/viewarticle.php?id=26\&layout $=\mathrm{html}>$. Acesso em: mar. 2004.

LIMA F⿳丷ㅡ, Henrique Espada. Microstoria: escalas, indícios e singularidades. Tese (Doutorado) - Universidade de Campinas, Campinas, 1999.

MENDONÇA, Marcos Carneiro de. A Amazônia na era pombalina; correspondência inédita do Governador e Capitão-General do Estado do GrãoPará e Maranhão Francisco Xavier de Mendonça Furtado. Rio de Janeiro: Instituto Histórico e Geográfico Brasileiro, 1963. v. 1, 2.

MENDONÇA, Marcos Carneiro de. Século XVIII, século pombalino do Brasil. Rio de Janeiro: Xerox do Brasil, 1989.

MONTEIRO, Jônathas da Costa Rego. A Colônia do Sacramento; 1680 -1777. Porto Alegre: Globo, 1937.

NEUMANN, Eduardo; KÜHN, Fábio. Resgate de fontes paroquiais; Porto Alegre e Viamão, século XVIII. $1^{\circ}$ Livro de Óbitos de Viamão. Porto Alegre. No prelo.

NOTÍCIAS PRÁTICAS. Bibliovirt/Liphis, 2002. Disponível em: < http:/ / www.liphis.com/buscadorcodigo/codigo.htm>. Acesso em: set. 2003.

PLÁSTICO INDUSTRIAL. São Paulo: Aranda, v. 5, n. 54, fev. 2003.

PEDREIRA, Jorge Miguel de Melo Viana. Os homens de negócio da Praça de Lisboa; de Pombal ao Vintismo (1755-1822): diferenciação, reprodução e identificação de um grupo social. 1995. Tese (Doutorado) - Universidade Nova de Lisboa, Lisboa, 1995.

PIAZZA, Walter Fernando. Açorianos e Madeireneses no Sul do Brasil. ACERVO: Revista do Arquivo Nacional, v.10, n.2, jul./dez. 1997.

PORTO, Aurélio. História das missões orientais do Uruguai. Rio de Janeiro: Imprensa Nacional, 1943. v.I.

PRADO, Fabrício Pereira. Colônia do Sacramento: o extremo sul da América Portuguesa. Porto Alegre: F. P. Prado, 2002.

PREFEITURA MUNICIPAL DE PORTO ALEGRE. Anais do Arquivo Histórico de Porto Alegre Moysés Vellinho. Porto Alegre, 1992.

QUEIROZ, Maria Luiza Bertuline. A Vila do Rio Grande de São Pedro. Rio Grande: FURG, 1987.

Anos 90, Porto Alegre, v. 12, n. 21/22, p.53-101, jan./dez. 2005 


\section{Martha Daisson Hameister}

SANTOS, Maria Licínia Fernandes dos. Os madeirenses na colonização do Brasil. Funchal: Centro de Estudos de História do Atlântico; Secretaria Regional do Turismo e Cultura, 1999.

VIEIRA, Alberto. Portugaly las Islas del Atlántico. Madri: Editorial Mapfre, 1992.

WIEDERSPHAN, Henrique Oscar. A colonização açoriana no Rio Grande do Sul. Porto Alegre: EST; Instituto Cultural Português, 1979.

\section{Fontes primárias manuscritas}

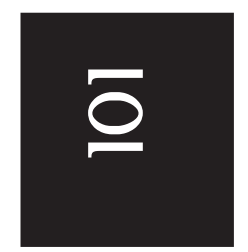

ARQUIVO DA DIOCESE PASTORAL DO RIO GRANDE. Livros 1ํ, $2^{\circ}, 3^{\circ} e$ $4^{\circ}$ de Batismos da Vila do Rio Grande 1738-1763.

ARQUIVO HISTÓRICO DA CÚRIA METROPOLITANA DE PORTO ALEGRE. Rol dos Confessados de Viamão- 1778.

ARQUIVO HISTÓRICO DO ESTADO DO RIO GRANDE DO SUL. Relação dos Moradores de Triunfo-1784, cód. F 1198-A.

ARQUIVO HISTÓRICO DO ESTADO DO RIO GRANDE DO SUL. Relação dos Moradores de Viamão, 1778.

Recebido em 11/11/2004

Aprovado em 25/04/2005

Anos 90, Porto Alegre, v. 12, n. 21/22, p.53-101, jan./dez. 2005 